\title{
Rute Kultural Musik Populer Di Madura
}

\author{
Ardhie Raditya ${ }^{1}$, Faruk, H.T², Wisma Nugraha Christianto ${ }^{3}$

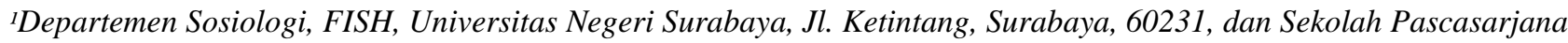 \\ Program Doktoral Kajian Budaya dan Media Universitas Gadjah Mada, \\ Jl. Teknika Utara, Pogung Kidul, Yogyakarta, 55281 \\ E-mail: diditz.kristina@gmail.com \\ ${ }^{2}$ Departemen Sastra Indonesia, FIB, dan Sekolah Sekolah Pascasarjana Program Studi Kajian Budaya dan Media Universitas \\ Gadjah Mada, Jl. Teknika Utara, Pogung Kidul, Yogyakarta, 55281 \\ E-mail: farukfaruk7676@gmail.com \\ ${ }^{3}$ Departemen Sastra Nusantara, FIB, dan Sekolah Sekolah Pascasarjana Program Studi Kajian Budaya dan Media Universitas \\ Gadjah Mada, Jl. Teknika Utara, Pogung Kidul, Yogyakarta, 55281 \\ E-mail: -
}

\begin{abstract}
Kemunculan musik populer di Madura yang mengalami perkembangan hingga sekarang tidak bisa lepas dari adanya pembukaan rute kultural. Rute kultural musik populer di Madura dimulai dari tengah pulaunya, kota Pamekasan, yang secara historis menjadi ibu kota pemerintahan Madura. Pada mulanya, kehadiran pusat hiburan seperti gedung bioskop telah melapangkan jalan bagi munculnya musik populer di Madura. Melalui bakat dan minat anak-anak muda setempat, musik populer tersebut lantas ditransfigurasikan ke dalam bentuk formasi band sebagaimana imajinasi musik populer yang mereka tonton di pusat hiburan. Rute ini perlahan menciptakan rute pendidikan musikal yang dilakukan secara otodidak atau di luar institusi sekolah musik formal melalui jalinan persahabatan lintas daerah. Hal ini dilakukan karena memainkan musik populer perlu dukungan perangkat teknologi musikal berskala dunia supaya tercipta ekologi musikal dan bebunyian yang mantap untuk dinikmati, baik musisi dan pendengarnya. Kapasitas memainkan dan menguasai perangkat teknologi musikal ini memberi kontribusi bagi jalan ketersohoran dan penyetaraan dunia musik populer anak muda Madura dan dunia musik serupa di tingkat lokal, translokal, bahkan, mungkin transnasional. Tetapi, rute kultural musik populer di Madura sulit memasuki rute bebas hambatan karena pelapisan orang Madura yang cenderung memberikan porsi besar bagi generasi tuanya sebagai penentu masa depan anak mudanya, termasuk, musik populernya.
\end{abstract}

Keywords—: Rute Kultural; Teknologi; Pelapisan Sosial; dan Musik Populer di Madura.

\section{LATAR BELAKANG}

Musik populer ada di mana-mana, di sekitar hidup kita, keberadaannya menembus batas-batas ruang dan waktu yang paling pribadi sekalipun, mulai dari kamar tidur hingga ketika kita sedang melamun. Sekalipun begitu, musik tidak sekedar harmoni dan melodi yang mewujud dari organisasi suara. Musik melampaui bentuk meterialnya. Musik memiliki kapasitas membentuk dan merubah realitas sosial. Oleh karena itu, musik merupakan alat memahami (a tool of understanding) dialektika antara basis dan superstruktur masyarakat (Attali, 1985). Beberapa waktu lalu, akhir September 2018 silam, di suatu masjid tempat tinggal Saya di Pamekasan-Madura. Seorang khotib menyampaikan khotbah Jumat yang mengejutkan nyaris setiap jemaahnya. Isinya tentang ajaran larangan bemusik dari hukum agama (Islam). Baginya, bermusik dapat menjauhkan diri dari mengingat Tuhan. Anak muda yang terlena godaan musik akan terganggu konsentrasi pendidikannya. Dengan suara berapi-api, sembari memelototkan mata, disertai jari telunjuk yang diarahkan ke langit-langit di atasnya, sang pengkhotnah mengajak para anak muda Madura yang gemar bermain musik populer segera bertobat.

Padahal, musik menggambarkan situasi spiritualitas. Meski kalangan sufiisme menganggap musik sebagai sarana mendekatkan pada sang pencipta, bagi sebagian kelompok muslim syariah gagasan musik seperti itu ditolak keras, bahkan, sangat mungkin dituduh 'sesat' (Schimmel, 2005: 9). Di Indonesia, musik memainkan peranan penting bagi upaya dakwah. Seperti yang dilakukan Sunan Bonang dengan lagu "Tombo Ati" dan "Ilir-Ilirnya", misalnya. Rhoma Irama, sang raja dangdut dengan soneta groupnya dikenal karya-karyanya bernafaskan musik Islami (Weintraub, 2003; Shofan, 2014). Selaras dengan itu, Cak Nun (panggilan akrab Emha Ainun Nadjib) pernah mengatakan kepada jemaah Maiyahnya bahwa musik pada dasarnya memiliki sifat kejujuran, yang menjadikannya 'sesat' karena sekelompok orang memagarinya dengan dalil keagamaan. Itulah sebabnya, Cak Nun tidak berbuat sewenang-wenang dengan melarang anak sulungnya memilih jalan sebagai anak band-bandan (Nadjib, 2015: 56). Sebab, musik bermuatan nilai-nilai kedamaain, kebersamaan, dan keagungan kosmis bagi pelakunya. Seperti halnya yang dilukiskan oleh Pramoedya Ananta Tour bahwa ketika bocah-bocah dan generasi muda berkumpul memanjatkan nyanyian bulan, sesekali diiringi sorak-sorai dan tepukan tangan, seluruh dunia seakan terbebas dari perang (Tour, 2002).

Namun, mengkaji musik, terutama musik populer di Indonesia, cenderung bermuatan politis. Selain ditopang berbagai kepentingan para pemainnya, perkembangan musik populer di Indonesia bertali-temati dengan situasi sosial, budaya, dan 
ekonomi masyarakat yang menyertai di baliknya. Pada rezim orde baru (orba) berkuasa musik modern yang pada era orde lama (orla) diasosiasikan secara negatif kemudian mendapat ruang yang lebih luas dari sebelumnya. Pada masa akhir dekade kekuasannya, rezim orba mulai mendukung gerakan politik kelompok intelektual muslim (ICMI). Dari beberapa anggotanya lantas mendominasi gerakan kesenian di Taman Ismail Marzuki (TIM), Jakarta. Dalam perkembangannya gerakan kesenian mereka menjadi standar acuan seni modern di Indonesia yang berkiblat pada dunia barat. Kendatipun demikian, seni modern (termasuk musik) mendapatkan tantangan serius dari mayoritas intelektual muslim. Upaya mereka merepresentasikan identitas seni Indonesia dengan mempertahankan perkawinan silang antara unsur tradisional dan sakralitasnya (Notosudirjo, 2011: 299305).

Selain itu, ruang lingkup media turut serta mengkonfigurasikan musik populer di Indonesia. Menurut penelitian Wallach, sekitar tahun 1970-an untuk pertama kalinya berbagai kaset, baik kaset musik populer barat dan Indonesia, diproduksi secara massal. Meskipun industri rekaman tersebut berpusat di Jakarta, kaset musik populer yang diproduksinya menjangkau masyarakat hingga seluruh nusantara. Antara industri rekaman global (Sony, WEA, BMG, dan Universal) dan nasional (seperti, Aquarius, Musica, Bulletin, dan Virgo Ramayana) saling berkompetisi memperebutkan pasar konsumer musik populer di Indonesia. Pada tahun 1995, untuk pertama kalinya MTV mengudara. Di dalamnya berbagai video musik, biografi musisi, album terbaru, tangga lagu, dan pengetahuan musik populer lainnya disuguhkan kepada para audiennya di Indonesia. Setidaknya, ada dua genre musik populer yang paling banyak diminta. Yakni, musik rock yang sarat kritik sosial dan musik pop yang bernafaskan nada cinta. Hanya saja, di antara masa kejayaan atau keemasan musik populer tersebut sejumlah artis musik populer Indonesia, seperti, Iwan Fals, Slank, dan Harry Roesli, dicekal, dicela, dan dijinakkan rezim orba. Karena, musik yang mereka mainkan bernuansa kritik keras kepada rezim orba. Hal ini menunjukkan bahwa media yang membentuk dunia musik (musicscape) di Indonesia tidak dapat dilihat dari konteks artefak musiknya semata-mata, melainkan juga konteks sosial yang melatarbelakanginya (Wallach, 2008).

Demikian halnya dengan dangdut. Sebagai bagian dari musik populer di Indonesia, dangdut tidak terbebas dari tarik-menarik pelbagai kepentingan dan kekuasaan. Masyarakat pada umumnya beranggapan bahwa dangdut merupakan genre musik populer otentik Indonesia. Keberadaannya memiliki kontribusi penumbuh dan penyebar semangat nasionalisme kultural. Rhoma Irama adalah sosok yang memiliki peran vital dalam mempopulerkan dangdut. Ia dianggap berhasil mengawinkan orkes melayu dan musik rock ke dalam musik dangdut. Umumnya, penggemarnya adalah masyarakat urban. Meskipun banyak cemoohan yang dilontarkan oleh para penggemar musik pop dan rock karena dianggap kekanak-kanakan, justru dangdut mampu menunjukkan eksistensinya di belantika musik Indonesia (Simatupang, 2013: 140-141). Namun, dangdut memicu kritik sekaligus pertanyaan ulang tentang makna otentisitas. Menurut Appadurai (1996) bahwa pada zaman globalisasi entitas budaya rentan terhadap perubahan sehingga memutus jaringan keutuhan dengan sejarah hidupnya yang telah mapan. Eksistensi suatu budaya bukan ditentukan oleh nostalgia masyarakatnya, tetapi dibentuk oleh imajinasi yang melibatkan adanya praktik sosial dan negosiasi antara posisi agen dan arena yang bersifat global (Appadurai, 2006). Pada kondisi demikian ini, entitas budaya mengalami juktaposisi, dan pengkaburan batas-batas. Sehingga, diperlukan perspektif kajian budaya dalam rangka mengkaji pengalaman hidup yang bersifat lokalitas dan translokalitas (Kraidy \& Murphy, 2003: 304).

Karena itulah, dangdut yang notabene dianggap sebagai produk budaya "original” Indonesia mendapat gugatan dari sejumlah intelektual budaya populer (Frederick, 1982). Weintraub (2003:35) mengatakan bahwa sulit kiranya mengklaim dangdut sebagai produk asli Indonesia hanya karena menggunakan unsur musikalitas melayu. Konsep melayu harus dilihat pada posisi aktor, lokasi, dan sejarah sosial budayanya yang spesifik, termasuk mereka yang berada di perkotaan. Jakarta, misalnya, yang pada mulanya menjadi lokasi sentral industri dangdut harus dilihat dari tiga aspek mendasar. Pertama, dikotomi cair antara orang kaya dan miskin, penduduk kota dan desa sebagai pendatang. Kedua, relasi antara sejarah Indonesia berbasis kelas sosial yang memiliki unsur-unsur kemenduaan (bifurcation). Ketiga, proses budaya yang tidak pernah tuntas dari para agennya di dalam merespon kehidupan kota (Wallach, 2008:43).

Meski demikian, musik populer paling banyak menyita perhatian anak muda Indonesia. Bagi mereka, musik bukanlah sekedar pengalaman hidup sehari-hari, melainkan juga kontestasi ideologis yang terwujud ke dalam banyak bentuk (Laughey, 2006). Bahkan, antara genre musik pop dan rock dibedakan secara ideologis (Wicke, 1987:91). Musik pop cenderung romantis, musik rock cenderung revolutif. Contohnya, adanya pertarungan sengit dalam bentuk konser akbar antara band papan atas beraliran dangdut dan musik rock pada tahun 70-an di Jakarta, hingga menimbulkan baku-hantam di antara penonton dan penggemarnya (Shofan, 2014). Kontestasi musik populer ini semakin mencolok karena negara menjadikan musik layaknya arena politik. Presiden Soekarno pernah menyampaikan kepada publik bahwa anak muda, baik perempuan dan laki-laki, harus bertekad bulat menjauhkan diri dari kontaminasi musik populer yang merupakan produk budaya imperialisme barat. Sekitar tahun 1988, bertepatan dengan perayaan ulang tahun TVRI, menteri penerangan, Harmoko, menyampaikan pidatonya bahwa musik rock adalah musik berselera rendah sekaligus 'menyimpang' dari spirit pembangunan. Pada tahun 1995, saat perayaan ulang tahun kemerdekaan RI, bertepatan dengan acara pembukaan program kontes dangdut di salah satu televisi nasional, sekretaris negara, Moerdiono, mendeklarasikan bahwa dangdut adalah musik dari rakyat, oleh rakyat, dan untuk rakyat Indonesia (Sen dan Hill, 2007: 170-174).

Namun, berbagai kajian musik populer di atas pada umumnya terpusat di level nasional yang menjadikan kota-kota besar di Indonesia sebagai ladang garapan penelitian. Padahal, mereka yang melihat dari jauh terkesan mengabaikan berbagai peristiwa musik populer di daerah. Pengalaman Heryanto, misalnya, ketika melakukan penelitian fenomena Inul Daratista, sosok artis dangdut papan atas pasca orba, yang disebutnya si "miskin-menjadi-kaya", merasa beruntung dapat turun langsung ke tempat 
Inul memulai karir musiknya di Pasuruan, kota kecil Jawa Timur. Biduan dangdut yang mulanya menggeluti musik cadas (rock) tersebut mendadak terkenal setelah berpindah haluan ke jalur dangdut. Dengan goyang ngebornya yang melekat pada identitasnya menjadikan Inul biduan dangdut paling fenomenal dan kontroversial. Sebab, selama beberapa dekade tampaknya belum pernah ada berbagai kekuatan ideologi di Indonesia secara terbuka, sengit, sarat muatan politik mempersoalkan penampilan Inul (Heryanto, 2012: 21-30).

Selain itu, musik populer yang awalnya menjadi objek 'penistaan' berangsur-angsur mulai membumi di Indonesia. Musik populer sebagai produk musik impor dari barat (Amerika dan Eropa) mengalami 'pribumisasi'. Menurut Sen dan Hill selama rezim orba 'bermesraan' dengan dangdut telah bermunculan musik 'underground' atau 'alternatif' beraliran rock melalui sejumlah konser dan radio sejak 90-an. Para peminatnya kebanyakan dari kalangan anak muda. Penjualan album band Slank, 'Generasi Biru', yang kiblatnya ke aliran musik rock asal Inggris, Led Zeppelin, misalnya, 43\% konsumennya tergolong anak muda berusia 15 hingga 19 tahun, 35\% lainnya berusia 20 hingga 24 tahun, dan 80\% di antara mereka adalah laki-laki. Dari sisi penggemarnya, mayoritas Slankers (sebutan para fans band Slank) berada di pulau Jawa. Yakni, 21\% di Jakarta, 18\% di Jawa Barat, 16\% di Jawa Tengah dan Yogyakarta, dan 2\% di Jawa Timur (Sen dan Hill, 2004: 80-81). Meskipun sepintas band The Beatles dianggap memberikan corak tersendiri bagi dunia musik rock di Indonesia, nyatanya kegarangan musik Led Zeppelin berhasil menghancurkan dominasi dunia musik lama yang seakan merayu-rayu sebagaimana kecenderungan umum musik Bob Dylan dan The Beatles.

Sebatas pengetahuan saya, kajian musik populer di Madura sangat langka, bahkan terbilang belum ada. Selama hidup dan besar di Madura, pengetahuan mengenai musik populer lebih banyak didapatkan dari media cetak, radio, serta perbincangan dari mulut ke mulut di antara anak band ala kadarnya. Di tengah kehidupan masyarakat mayoritas muslim perkara musik populer atau bernuansa 'modern' rentan terhadap penilain dikotomis 'halal-haram' (Harnish dan Rasmussen, 2011). Madura yang dikenal sebagai 'serambi madinah' dengan mayoritas penduduknya beragama Islam, kehadiran musik populer, baik dangdut, rock, pop, dan genre musik populer lainnya, belakangan ini mendapat label buruk, tercela, dan menyimpang secara kultural karena pandangan sepihak kelompok Islam tertentu. Meskipun sejak dekade akhir rezim orba hingga separuh perjalanan pasca orba keberadaan musik populer di Madura terbilang pesat, kondisi demikian mulai berjalan surut pada pasca orba.

Ketika demokrasi di Indonesia telah dimulai, salah satunya ditandai terbukanya kesempatan berekspresi, termasuk pula dalam bermusik, musik populer yang menyedot perhatian anak mudanya justru tampak lunglai, bahkan terancam kepunahan di Madura. Semasa sekolah di Pamekasan yang terkenal sebagai kota pendidikan di Madura, berbagai album kaset band musik populer dari bertaraf nasional hingga global begitu mudahnya saya dapatkan. Di kala itu pula, mengikuti berbagai konser dan festival musik populer seperti dangdut, rock, pop, dan sejenisnya menjadi kebanggaan tersendiri bagi kalangan anak muda (dhâd-ngodedhân) Madura. Namun, sejak dikeluarkannya keputusan bupati No.188/126/441.012/2012 tentang pemberlakuan daerah 'Gerbang Salam' (Gerakan pembangunan masyarakat Islami) yang digagas oleh LP2SI (Lembaga Pengkajian dan Penerapan Syariat Islam) di bawah naungan pemerintah daerah, denyut nadi musik populer di sana lambat laun mulai melemah.

Berdasarkan hasil penelusuran online menunjukkan bahwa topik penelitian musik populer di Madura tampaknya belum tergarap secara spesifik, mendalam, rinci, dan serius (tabel 1.). Karena, tema penelitian masyarakat Madura didominasi isu agama, kekuatan elit lokal, kekerasan, masyarakat agraris dan pesisir, kerapan sapi, dan budaya tradisional Madura lainnya. Sehingga, tema penelitian Madura ini terkesan seperti mencitrakan bahwa orang Madura jauh tertinggal dibandingkan daerahdaerah di luar pulaunya dalam perkembangan musik populernya.

Tabel 1. Tema Penelitian Budaya Madura Bersumber dari Google Scholar dan Google

\begin{tabular}{|c|c|c|c|c|}
\hline Sumber Data & Tema Tulisan & Nama Pengarang & Dirujuk & Tahun Terbit \\
\hline \multirow[b]{9}{*}{ Google Scholar } & $\begin{array}{l}\text { Tradisi Makan } \\
\text { (Rice Culture in Java } \\
\text { and Madura) }\end{array}$ & $\begin{array}{l}\text { Van der Giessen } \\
\text { (Netherland) }\end{array}$ & 3 kali & 1943 \\
\hline & $\begin{array}{c}\text { Kemaritiman } \\
\text { (Maritime of Madura) }\end{array}$ & $\begin{array}{c}\text { Kurt Stenross } \\
\text { (Murdoch University) }\end{array}$ & 3 kali & 2007 \\
\hline & $\begin{array}{l}\text { Budaya Kekerasan } \\
\text { (Violence in Madura) }\end{array}$ & $\begin{array}{l}\text { Glenn Smith } \\
\text { (EHESS Paris) }\end{array}$ & 3 kali & 2004 \\
\hline & $\begin{array}{c}\text { Pengobatan Rakyat } \\
\text { (Folk Medicine in } \\
\text { Madura) }\end{array}$ & $\begin{array}{c}\text { RE Jordaan } \\
\text { (Leiden University) }\end{array}$ & 29 kali & 1985 \\
\hline & Blater Madura & $\begin{array}{c}\text { Abdur Rozaki } \\
\text { (Universitas Gadjah Mada) }\end{array}$ & 2 kali & 2008 \\
\hline & Kiai dan Klebun & $\begin{array}{c}\text { ME Saputro } \\
\text { (Universitas Gadjah Mada) }\end{array}$ & 2 kali & 2009 \\
\hline & Carok & $\begin{array}{c}\text { Latief Wiyata } \\
\text { (Universitas Jember) }\end{array}$ & 59 kali & 2002 \\
\hline & $\begin{array}{c}\text { Politik Keamanan } \\
\text { Jagoan Madura }\end{array}$ & $\begin{array}{c}\text { Ardhie Raditya } \\
\text { (Universitas Negeri Surabaya) }\end{array}$ & 4 kali & 2012 \\
\hline & Mencari Madura & $\begin{array}{c}\text { Latief Wiyata } \\
\text { (Universitas Jember) }\end{array}$ & 3 kali & 2013 \\
\hline
\end{tabular}


Website : http://sosial.unmermadiun.ac.id/index.php/sosial

\begin{tabular}{|c|c|c|c|c|}
\hline \multirow{2}{*}{$\begin{array}{l}\text { (29.100 hasil dari kata } \\
\text { kunci: } \text { Culture and } \\
\frac{\text { Arts of Music in }}{\text { Madura })}\end{array}$} & Manusia Madura & $\begin{array}{l}\text { Mien Rifai } \\
\text { (AIPI) }\end{array}$ & 7 kali & 2007 \\
\hline & $\begin{array}{l}\text { Lèbur: Seni Musik dan } \\
\text { Pertunjukan di Madura }\end{array}$ & $\begin{array}{l}\text { Hélèna Bouvier } \\
\text { (EHESS Paris) }\end{array}$ & 16 kali & 2002 \\
\hline \multirow{9}{*}{$\begin{array}{c}\text { Google } \\
\text { (1.380 Juta hasil dari } \\
\text { kata kunci: Penelitian } \\
\text { Madura) }\end{array}$} & Topeng Dalam Madura & $\begin{array}{l}\text { Willy Hanto, dkk } \\
\text { (STSI Surakarta) }\end{array}$ & - & 1997 \\
\hline & $\begin{array}{c}\text { Interaksi Sosial } \\
\text { Keturunan Madura di } \\
\text { Malang }\end{array}$ & $\begin{array}{c}\text { Qaharuddin Widyarto } \\
\text { (Universitas Negeri Malang) }\end{array}$ & - & 2012 \\
\hline & Ramuan Madura & $\begin{array}{c}\text { Lestari Handayani } \\
\text { (Universitas Airlangga) }\end{array}$ & - & 2003 \\
\hline & $\begin{array}{l}\text { Ketoprak "Rukun } \\
\text { Family" }\end{array}$ & STKIP Bangkalan & - & 2013 \\
\hline & $\begin{array}{c}\text { Arsitektur Rumah } \\
\text { Tinggal Tradisional } \\
\text { Madura }\end{array}$ & $\begin{array}{c}\text { Tim Peneliti Universitas } \\
\text { Brawijaya }\end{array}$ & - & 1991 \\
\hline & $\begin{array}{l}\text { Agama dan Budaya } \\
\text { Orang Madura }\end{array}$ & $\begin{array}{c}\text { Mutmainnah } \\
\text { (Universitas Trunojoyo Madura) }\end{array}$ & - & 2007 \\
\hline & $\begin{array}{c}\text { Produktivitas Sapi } \\
\text { Madura }\end{array}$ & $\begin{array}{c}\text { Johar Arifin } \\
\text { (Universitas Padjajaran) }\end{array}$ & - & 2007 \\
\hline & $\begin{array}{c}\text { Mempertahankan } \\
\text { Bahasa Madura }\end{array}$ & $\begin{array}{l}\text { Akhmad Sofyan dan Bambang } \\
\text { Wibisono (Universitas Jember) }\end{array}$ & - & 2013 \\
\hline & $\begin{array}{l}\text { Nelayan Tradisional } \\
\text { di Pamekasan-Madura }\end{array}$ & $\begin{array}{l}\text { Karjadi Mintaroem dan Imam } \\
\text { Farisi (Universitas Terbuka) }\end{array}$ & - & 2000 \\
\hline
\end{tabular}

Sejak merebaknya televisi ke pulau Madura pada dekade 1980-an, berbagai program budaya populer, seperti dangdut dan film Hollywood menjadi tontonan massal di Madura. Menurut informasi yang beredar bahwa tahun 80-an, televisi hanya dimiliki orang kaya. Dalam satu kampung barangkali hanya kepala desa (klèbun) dan juragan yang memilikinya. Selain televisi itu, gedung bioskop turut mendukung perkembangan musik populer di Madura. Setiap kabupaten di Madura, minimal terdapat satu gedung bioskop berukuran kecil dengan kapasitas tampung rata-rata 500 penonton. Tiga gedung bioskop megah justru berada di Pamekasan, karena di daerah ini merupakan jantung ibu kota pulau Madura. Kapasitas tampungnya rata-rata di atas 500 orang, bahkan, bisa mencapai di atas 1000 orang. Menurut catatan Rifai (1993: 85) bahwa antara tahun 1950-1966 adalah sejarah masuknya televisi dan berdirinya gedung bioskop di Madura. Tontonan populer pada masa itu adalah film-film India, Eropa, dan Amerika, termasuk film musikal tentang Elvis Presley, The Beatles, "Little House on the Praire", "Rock Around the Clock", dan lainnya. Karena Madura bisa dikatakan tidak memiliki gedung budaya, maka gedung bioskop kerap berubah fungsi menjadi tempat pertunjukan pentas kesenian: peragaan busana, konser musik, festival rock, kontes tarik suara, dan lain sebagainya.

Pasca orba, kemeriahan musik populer yang memadati gedung bioskop maupun di lapangan terbuka di pusat-pusat kota di Madura mendapat ancaman serius dari kelompok-kelompok ormas keagamaan yang mengatasnamakan dirinya sebagai pembela ajaran Syariat Islam. Pemeritah daerah setempat kadangkala tidak mampu mengatasinya sehingga sejumlah pagelaran musik populer batal digelar karena desakan politik mereka. Peterpan, Samsons, Five Minutes, Ridho Rhoma, Kangen Band, yang sempat singgah di jantung ibu kota Madura terpaksa angkat kaki setelah justru ketika mereka telah datang dan bersiap-siap akan tampil menyubuhkan karya musikal mereka. Kerugian material hingga puluhan juta harus ditanggung panitia, termasuk kerugian non material karena pihak panitia mendapatkan trauma psikologis dan potensi ketidakpercayaan publik. Lebih tragisnya lagi, pusat-pusat kota yang menjadi akses bagi semua warga Madura, tua maupun muda, sebagai bagian dari ruang terbuka bagi pemenuhan kebutuhan hiburan dan penyaluran bakat-bakat seni terpaksa 'dimonopoli' oleh sekelompok orang yang tidak toleran bagi siapa saja yang tidak mengikuti ajaran agama mereka. Padahal, musik populer bisa menjadi media penyaluran agresifitas anak mudanya. Penelitian yang dilakukan McDonald di Melbourne barat, misalnya, dengan melibatkan 3600 anak mudanya, mengungkapkan adanya harapan bahwa kota seharusnya menjadi bagian dari "wajah" budaya anak muda. Karena itu, pemerintah terkait perlu menyediakan fasilitas bagi budaya populer anak muda, termasuk dukungan moral dan kebijakan bagi keberlangsungan hidup musik populer anak mudanya. Dengan dukungan seperti ini mengisyaratkan bahwa anak muda dimanusiawikan dan mendapatkan penyaluran sesuatu yang positif. Musik populer bukan sekedar memenuhi kebutuhan estetis, melainkan juga sebagai media interkoneksi di antara anak muda dengan berbagai dimensi budayanya (McDonald, 1999: 25). Karena itulah, supaya musik populer di Madura tidak benar-benar lenyap dari kehidupan orang Madura maka pada tulisan ini Saya akan mengetengahkan rute kultural musik populer di Madura yang pernah dilalui dan disinggahi oleh pelakunya sehingga, dari sanalah dunia kehidupan musik populer di Madura dimulai. 


\section{METODE PENELITIAN}

Tulisan ini menggunakan dua pendekatan metode kualitatif, posfenomenologi dan etnografi. Prinsip Posfenomenologi ini didasarkan pada proses saling silang-menyilang antara mikropersepsi dan makropersepi. Mikropersepsi mengacu pada dimensi sensor tubuh seperti perspesi dan refleksi, sedangkan fokus makropersepsi pada dimensi hermeneutik-budaya (Ihde, 1993: 74). Makropersepsi ini juga mengandalkan informasi teksisme tentang suatu yang terlihat dan tidak terlihat sebagai produk budaya, sehingga, dibutuhkan aktivitas navigasi untuk menyingkapnya (hal, 75-76). 'Teks' menurut Ihde terdiri dari bahasa tertulis dan terbaca (write-read) serta terucapkan dan terdengar (speech-heard) yang memungkinkan perbedaan pemahaman dan pemaknaan dari masing-masing orang karena perbedaan kepentingan, pengalaman, dan pengetahuan (hal. 88-90). Budaya teknologi bisa menjadi salah satu kerangka penting di dalam posfenomenologi. Teknologi adalah penghubung antara keberadaan manusia dan 'kealaman'. Posfenomenologi pada konteks ini tidak mengabaikan relasional manusia-mesin (phenomenology of human-machine relation) untuk memahami bahwa kehidupan kita tak bisa lepas dari budaya teknologis (Ihde, 1979: 3). Teknologi tidak hanya perangkat keras, melainkan juga berarti serangkaian artefak yang berkaitan dengan konteks praksis (semisal, teknik penggunaannya) (Ihde, 2007: 32). Di dalam dunia musik, tentu teknologi menjadi sangat penting. Ketika pengalaman menubuh di dalam dan melalui peralatan, bebunyian (sound) dan cara mendengarkan (way of listening) mengalami transformasi pasca revolusi teknologi komunikasi, sehingga, produksi teknologi bebunyian seperti hingarbingar suara The Beatles dan Beethoven menghampiri hidup kita melewati ruangan berstereo (Ihde, 1993: 4).

Kedua, pendekatan etnografi multi situs. Untuk mengungkap dimensi budaya secara lebih mantap, fenomenologi perlu dikombinasikan dengan pendekatan etnografi. Sebagai 'anak kandung' fenomenologi, etnografi menekankan pentingnya kehidupan sehari-hari 'orang-orang lokal' dengan kekhasan bahasa dan keterlibatan mereka sendiri dalam mengkonstruksi budayanya (Willis, 2014). Etnografi sebagai praktik metodologis ditandai oleh keterkaitannya antara paket metode penelitian dan penulisan (deskriptif-analitik, emik, dengan mempertimbangkan istilah lokal) (Simatupang, 2013). Etnografi seni merangkai makna (meaning-making) dengan cara partisipasi, interaksi, dan observasi informal pada jangka waktu tertentu untuk menjawab teka-teki sosial (social puzzle) yang disusun sedemikian rupa sebagai tema dan isu penelitian (Willis, 2000). Kerja lapangan ini mencoba memahami budaya masyarakat atau kelompok sosial dengan cara mengintegrasikan antara investigasi data empiris, teoritis dan interpretasi komparatif akan budaya dan organisasi sosialnya (Hammersley dan Atkinson, 2007).

Namun, di zaman globalisasi apa yang dimaksud lapangan penelitian sosial budaya menurut Clifford (1997) memunculkan rute-rute kultural yang bergerak ke berbagai arah, dari 'barat ke timur' maupun 'timur ke barat', sehingga, mendorong etnografer untuk melakukan penjelajahan ke mana-mana dan sewaktu-waktu bisa berhenti sejenak di tengah perjalanannya (dwelling in travel). Karena itu, kerja lapangan yang mulanya sebagai citra mental dengan menitikberatkan pada gerakan praktik fisikal berubah ke praktik 'spasial'. Pendekatan Antropologi sosial budaya ini mengajak etnografer melakukan praktik 'spasial': tinggal di komunitas secara temporal, bergerak dari 'dalam' (in) ke 'luar' (out), keluar-masuk, datang-pergi secara sistematis (hal. 57). Keserbaragaman ruang kehidupan ini membutuhkan pendekatan alternatif, yakni, etnografi multi situs.

\section{III.HASIL DAN PEMBAHASAN}

\section{A. Kondisi Sosial Geografis 'Pusaka di atas Khatulistiwa'}

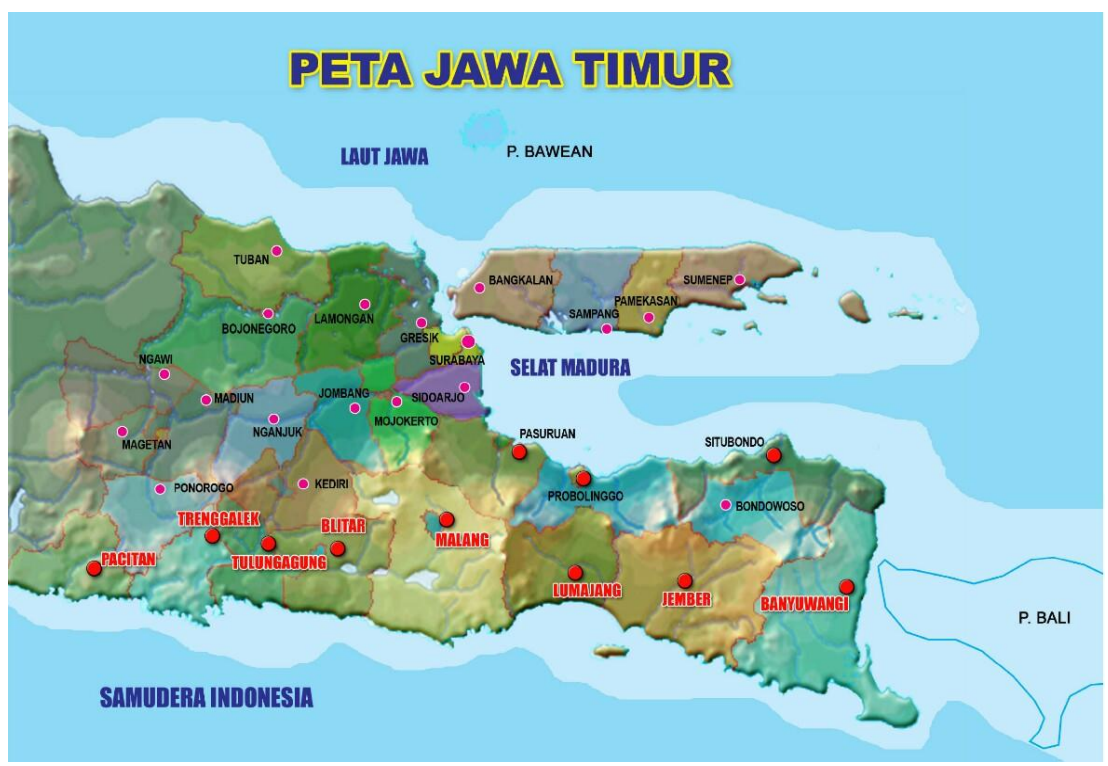

Gambar 1. Madura dalam peta wilayah Jawa Timur (Foto: Ara)

Hubungan Madura dengan daerah-daerah terluarnya, hingga menjalin dimensi hubungan internasional dengan daerah-daerah mancanegara, telah berlangsung sejak lama, bahkan, jauh sebelum Indonesia merdeka. Sejak pertengahan abad ke-19, kolonial 
Belanda mengenalkan pemerintahan langsung di Madura, mengakhiri sistem pemerintahan kerajaan, dan sejak tahun 1858 Pamekasan merupakan ibu kota pulau Madura, berdampingan dengan kota-kota lainnya di Madura, di mana jumlah penduduk di tiap-tiap kota itu hanyalah 10\% dari seluruh jumlah penduduk Madura yang $90 \%$ hidupnya berpencar-pencar di lingkungan pertanian (De Jonge, 1989). Walaupun letak geografis pulau Madura terpisah dari daratan pantai Jawa Timur, pada kenyataan historisnya menunjukkan bahwa pulau ini sejak lama merupakan kesatuan daratan Jawa, baik dalam politik, ekonomi, sosial dan dalam beberapa hal aspek kebudayaannya (Sutjipto, 1977). Globalisasi yang merupakan fenomena konektivitas dunia (Robertson dan Kathleen, 2007) dan memproduksi latar lokalitas melalui rekognisi konteks kedekatan hidup sesamanya yang menyulut terjadinya kekerasan, kekacauan, serta pemberontakan dalam momen kolonialisasi (Appadurai, 1996), menjadi bagian tidak terpisahkan dalam sejarah panjang kehidupan di pulau Madura.

Pulau Madura masih berada dalam wilayah administratif Jawa Timur yang terdiri dari empat kabupaten (gambar 2.). Secara berturut-turut, keempat kabupaten tersebut dari ujung barat ke ujung timurnya adalah Bangkalan, Sampang, Pamekasan, dan Sumenep. Sumenep adalah kabupaten terluas di antara empat kabupaten di Madura lainnya. Luas masing-masing kabupaten itu adalah: Bangkalan $1.260 \mathrm{~km}^{2}$, Sampang $1.233 \mathrm{~km}^{2}$, Pamekasan $792 \mathrm{~km}^{2}$, serta Sumenep $1.989 \mathrm{~km}^{2}$. Total luas lahan di pulau Madura adalah 469,590 ha, dengan rincian: Bangkalan 116,607 ha, Sampang 123,084 ha, Pamekasan 77 ha, dan Sumenep 152,104 ha. Letak pulau Madura ini berada di pojok timur laut pulau Jawa yang bagian ujung timur laut pulaunya berbatasan langsung dengan selat Bali. Karena Madura dikelilingi oleh lautan (laut Jawa, selat Bali, dan selat Madura), maka sebutan pulau menjadi melekat padanya. Posisi geografis pulau ini yang terletak di sebelah timur laut pulau Jawa dengan koordinat $7^{\circ}$ lintang selatan bumi, seakan kedua ujungnya tergantung antara $112^{\circ}$ dan $114^{\circ}$ bujur timur, panjang pulaunya sekitar $190 \mathrm{~km}$ dan jarak terlebarnya $40 \mathrm{~km}$ sehingga luasnya mencapai $5.304 \mathrm{~km}^{2}$, dengan ketinggian pulaunya antara 2 hingga 350 meter dari permukaan laut menjadikan pulau Madura ini tampak terlihat seperti ukiran sebilah belati di atas khatulistiwa (Rifai, 2007: 23). Apabila visualisasi peta geografis pulau Madura ini menandakan pusaka sebilah belati yang terbungkus rapi maka, Pamekasan diposisikan sebagai ujung pembelahnya. Sebab, koordinat Pamekasan berada di antara $6^{\circ} 51-7^{\circ} 31$ Lintang Selatan dan $113^{\circ} 19$ $113^{\circ} 58$ Bujur Timur yang garis pembatas daerahnya di sisi sebelah timur dan baratnya beririsan langsung dengan batas barat Sumenep dan timur Sampang.

Posisi geografis Pamekasan sebagai ujung belati di atas memiliki dua makna penting. Pertama, sebagai penghubung antara rangka dan gagang belati. Kedua, sebagai ujung masuk penutup (sarung) belatinya. Apabila dihubungkan dengan masa-masa kejayaan kerajaan masa silam, maka boleh jadi belati yang dimaksud ini adalah keris. Sebagaimana halnya keris, pada bagian rangka dan sarung (bhârengka) keris selalu terdapat spesifikasi alat penghubung di ujung pangkalnya. Perangkat penghubung di antara jalur sarung dan rangka keris tersebut adalah sampir (leher). Sampir ini disebut sebagai jalan utama keluar masuknya keris dari dan ke dalam bhârengka. Oleh sebab itu, Pamekasan dianggap daerah sentral yang secara komplementer mengikat, menghubungkan, dan memperkuat ikatan geopolitik di antara empat daerah pulau Madura. Siapa yang menguasai Pamekasan akan menguasai pulau Madura separuhnya, tiga perempatnya, atau bahkan mungkin secara keseluruhan. Perlawanan Trunojoyo yang berhasil melumpuhkan dominasi Mataram abad ketujuh belas juga berawal dari Pamekasan, karena sebagian besar pangkalan perangnya konon bermula dari sana (Rifai, 1993: 35). Beralasan kiranya apabila lambang resmi daerah Pamekasan digambarkan sebilah keris yang posisinya berada tepat di bagian tengah paling pucuk atap keratonnya. Kendatipun demikian, visualisasi peta pulau Madura bisa diibaratkan pula gitar organ yang mengambang di atas khatulistiwa dan pada bagian ujungnya memancarkan semburan kembang api yang indah. Karena gitar organ jarang sekali digunakan sebagai instrumen utama kelompok pemain band, kalah prestisius dengan instrumen gitar dan drum maka, gitar organ tersebut tergolong barang antik atau 'pusaka subsitusi' dalam dunia musik populer orang Madura.

Sebelum kekuatan ambisius Sultan Agung ingin menguasai tanah Jawa, termasuk juga pulau Madura, pada permulaan abad ke-17, Madura hanya terdiri dari dua area kerajaan yang terhampar dari Sumenep dan Pamekasan. Sampang kala itu hanyalah kepatihan atau semacam keraton kecil di Madekan yang ditempati oleh kamituwa dari Majapahit dan masih memiliki ikatan darah dengan leluhur kerajaan Pamekasan. Setelah keturunan keduanya ini terikat oleh pernikahan keluarga maka, praktis Madekan menjadi kesatuan wilayah dengan Pamekasan. Setelah pulau ini dapat dikuasai Mataram hingga mengobarkan episode perlawanan tragis dan dramatis oleh pangeran Trunojoyo, keturunan Sultan Agung, yang ayahnya berdarah Madura tewas dibunuh kerabatnya karena intrik politik Mataram maka, Madura pasca Trunojoyo itu dibelah menjadi dua daerah, Madura barat (Bangkalan) dan Madura timur (Pamekasan hingga Sumenep) (Abdurachman, 1971: 26-27). Pada zaman rezim kolonial, sampai saat pemerintah Hindia Belanda menyerah kepada Jepang tanggal 8 Maret 1942, pemerintahan Madura diselenggarakan oleh Residen Belanda, ibu kotanya berkedudukan di kota Pamekasan, dan Residen Belanda ini membawahi tiga kabupaten (Bangkalan, Pamekasan, hingga Sumenep), sedangkan Sampang statusnya berupa kawedanan yang berada di bawah naungan Pamekasan (Djojoprajitno, 1988: 5). Karena perjalanan sejarah geopolitik ini, sebagian besar orang-orang Madura mengatakan "entarra ka Bâre"” (menuju ke barat) sebagai petunjuk arah perjalanannya menuju ke Sampang dan Bangkalan maupun ke luar pulau Madura. Begitu pula sebaliknya, "entarrah ka Tèmor" (menuju ke timur) untuk menunjuk arah tujuannya ke daerah Pamekasan dan Sumenep maupun pulau terluar di ujung timur Madura. Tetapi, mereka acapkali mengatakan "entarrah ka tengnga" (menuju ke tengah) ketika jalur perjalanan dari daerah barat dan timur hendak menuju Pamekasan. Itulah sebabnya, Pamekasan yang posisi geografisnya tampak lentur, bisa menjangkau sebagian daerah Madura Barat dan sebagian juga Madura Timur maka, beberapa di antara mereka berseloroh bahwa orang Pamekasan adalah kelompok "Timur Tengahnya" pulau Madura. 


\section{B. Pelapisan Sosial Budaya Orang Madura}

Pada tahun 1750-an, ketika Madura berada dalam cengkraman pemerintahan VOC, kerajaan Sumenep dipimpin seorang ratu perempuan untuk pertama kalinya yang bernama Ratu Tirtonegoro. Suatu malam dia mendapatkan mimpi untuk menikahi Bendoro Saut agar keturunannya kelak menjadi penerus tahtanya selama tujuh turunan. Bendoro Saut yang kala itu sudah menikah dengan Nyai Isza, keturunan sunan Paddusan (salah satu anak dari Sunan Kudus), tidak bisa berbuat banyak selain mengikuti titah ratunya. Maka, pada 30 April 1751 dia dinobatkan langsung oleh VOC di Semarang sebagai bupati Sumenep dan dianugerahi gelar Tumenggung Tirtonegoro. Tetapi, Patih Purwonegoro yang berambisi menduduki posisi Bupati Sumenep merasa marah dan berusaha membunuhnya. Dia tidak pernah hadir di dalam pertemuan penting kerajaan sebagai protes kerasnya. Untuk kesekian kalinya, seluruh jajaran pejabat kerajaan diminta menghadap, termasuk sang Patih, sebagai 'teater' mengenalkan Tumenggung Tirtonegoro yang telah dilantik dan memusyawarahkan persoalan masa depan pembangunan. Pada waktu ini, Patih Purwonegoro menyempatkan datang dan berencana menghunuskan pedang pada raja barunya. Untuk mengantisipasi kemurkaan sang Patih maka, ditunjuklah seorang menteri Kijahi Sawung Galing agar menyamar sebagai Tumenggung Tirtonegoro. Sesampai di istana, Patih Purwonegoro duduk tepat di depan singgasana sang Tumenggung. Tibatiba, dia menghunuskan pedangnya. Sialnya, pedang tajamnya meleset dan seketika itu sang menteri menusukkan kerisnya, begitu pula sang menteri Kijahi Singotaruno yang berada di sebelahnya ikut menghunuskan tombak pusaka kepadanya. Sang Patih terkapar dan tewas seketika. Sejak peristiwa ini, Tumenggung Tirtonegoro mengeluarkan maklumat pertamanya bahwa seluruh keluarga besar kerajaan, baik keturunan raja maupun para pejabat istana, yang memakai gelar kebangsawan seperti, Raden, Raden Panji, Raden Ario, dan lain sebagainya harus diubah gelarnya menjadi "Kijahi”. Mereka wajib bersumpah setia kepada rajanya agar senantiasa menjunjung tata tertib dan tata kesopanan dalam kehidupan sehari-harinya hingga tujuh turunan kelak. Mereka yang tidak sudi dengan keputusan ini harus keluar dari kerajaan. Sebagian keturunan bangsawan yang menolak keputusan ini terpaksa pergi kembali ke pihak keluarganya yang berada di daerah Pamekasan dan sekitarnya. Sebagian lainnya tetap tinggal di lingkungan istana dan mematuhi sumpah setianya menjaga kesopanan selama berada di bawah pemerintahan trah Bendoro Saut hingga tujuh turunan (Zainalfattah, 1912: 64-67).

Barangkali atas dasar babak sejarah itulah kemudian membuat orang-orang di Madura kerapkali memanggil sebutan "Bupati" dengan embel-embel "Kanjeng Bupati". Tetapi, pasca berakhirnya kekuasan kolonial Belanda dan hadirnya Residen pertama di Madura, Soenarto, putra daerah Pamekasan, panggilan semacam itu dilarang digunakan karena dianggap warisan budaya kolonial serta tidak sesuai dengan kehidupan bangsa yang telah merdeka. Hanya saja, begitu kuatnya pengaruh budaya kesopanan yang telah berabad-abad diterapkan di pulau ini sulit melepaskan orang-orang Madura dari bayang-bayangnya. Karena itu, dalam percakapan sehari-hari terdapat hirarki bahasa yang dipergunakan oleh orang-orang Madura. Yakni, enjâ-iyâ, èngghi-enten, dan èngghi-bhunten. Bahasa enjâ-iyâ termasuk tingkat bahasa yang paling rendah. Bahasa ini umumnya digunakan hanya di dalam pergaulan sesama teman sebaya atau yang setara karena keakrabannya. Bahasa èngghi-enten biasanya lebih halus dari bahasa enjâ-iyâ. Biasanya digunakan di dalam situasi formal dengan tujuan menghargai lawan bicaranya. Anak-anak muda cenderung menggunakan bahasa menengah ini jika lawan bicaranya adalah orang yang dianggap lebih tua. Sementara itu, èngghi-bhunten adalah tingkatan bahasa yang paling halus. Bahasa halus ini dipergunakan oleh seseorang jika berhadapan dengan orang tua Madura yang terdiri dari bhuppa'-bhâbhu', ghuru, ratoh (orang tua, guru, dan raja). Semakin halus bahasa yang dipergunakan maka seseorang akan mendapatkan penilaian di masyarakat sekitar sebagai orang yang memiliki sopan santun, berbudi luhur, dan beradab. Sebaliknya, mereka yang tidak tahu dan enggan berbahasa halus kepada orang tua Madura akan dianggap jânggâl maupun mapas (tidak tahu tatakrama) (Wiyata, 2002). Sebagai pelengkap kesempurnaan berbahasa maka, selama berkomunikasi dengan orang tua Madura sangat dianjurkan anak-anak muda dan orangorang yang lebih rendah usia serta status sosialnya untuk menundukkan kepalanya, menyilangkan kedua tangannya di depan perutnya, dan meminimalisir tatapannya ke muka lawan bicaranya agar tidak dianggap menantang atau bersikap kurang ajar yang di dalam pribahasa Madura disebut perbuatan metta' bhuri' tengnga lorong (memperlihatkan bokongnya di tengah jalan). Bahasa simbolis yang terkait sopan-santun ini tidak hanya dalam hal bahasa tuturan, melainkan juga terlihat pada pengendalian sikap tubuhnya. Di dalam sikap duduk, misalnya. Ketika di dalam ruangan terdapat orang tua Madura maka, sikap duduk anakanak muda tidak boleh sembarangan. Semisal, harus turun dari kursi ketika orang tua sedang duduk di lantai. Ketika mendengarkan nasehat dan perintah orang tua, mereka juga tidak boleh aḍ̂nga (mendongak) sekalipun apa yang dikatakan orang tua Madura ini tidak sesuai dengan kehendak hatinya.

Ketiga tingkatan bahasa Madura tersebut pada masa kolonial menjadi acuan identitas sosial seseorang karena bahasa menunjukkan hirarki sosial dan darimana status sosial mereka berasal. Menurut Muakman dalam buletin Pakem Maddhu, kopeng 33/Th.8/Nopember/2012 (hal. 29) bahwa tingkatan bahasa itu meliputi cara berbahasa kelas bawah/rakyat kecil (réng kéni'), parjaji (kelas menengah atau pegawai di pemerintahan Belanda), dan kelompok kaom ningrat/kelas atas (kelompok bangsawan). Dalam penuturan sehari-harinya, bahasa enjâ-iyâ biasanya digunakan oleh kelompok rakyat kecil, èngghi-enten di kalangan kelas menengah, sedangkan, èngghi-bhunten di kelompok bangsawan. Penggunaan tingkatan bahasa ini mulai berubah, dari 'atas ke bawah' atau 'bawah ke atas' ketika seseorang yang berasal dari hirarki sosial terbawah di Madura berhadapan orang yang berasal dari kelas sosial atas. Semisal, kata 'Saya' atau 'séngko' (bahasa enjâ-iyâ) berubah menjadi 'abdhi dhâlem' (bahasa èngghi-bhunten) ketika seseorang berkomunikasi dan berhadapan dengan orang yang lebih tinggi status sosialnya. Sebaliknya, orang yang statusnya lebih tinggi akan menyebut kata 'dhikah' (kamu) ketika berkomunikasi dan berhadapan dengan seseorang yang lebih rendah status sosialnya. "Bhasâ nodhuwaghi bhângsanah" (bahasa mencerminkan bangsa atau komunitas penuturnya), demikian slogan berbahasa orang Madura. Buletin Pakem Maddhu yang berisi informasi dan 
pengetahuan bahasa Madura juga mempunyai slogan "Merté bhâsa, ngopéné bhudhâjâ bhângsa” (memahami bahasa, merawat budaya bangsa).

Supaya mudah mengenali ciri perbedaannya maka, setidaknya dapat ditengarai dari kata penunjuk diri, 'saya' dan 'kamu' 'Saya' dan 'kamu' dalam penuturan bahasa enjâ-iyâ adalah sengko' dan bâ'na atau be'en. Bahasa èngghi-entennya adalah bulâ dan dhika. Bahasa èngghi-bhuntennya adalah 'abdhina dan ajunan atau sampéyan. Tetapi, di luar bahasa Madura ini terdapat juga bahasa ragam kota atau dikenal bhâsa mlajuh yang kata tunjuk diri menggunakan kosakata bahasa Indonesia 'Saya' dan 'saudara' atau 'situh' yang dicampur dengan bahasa Madura (Sofyan dan Haryono, 2009: 7). Contoh di dalam susunan kalimat, misalnya, "situh kemana'ah?" (Saudara mau kemana?), atau "Saya ngater binih" (Saya tadi mengantar istri). Pada umumnya, para pengguna bahasa ragam kota atau bahasa campuran Indonesia-Madura ini adalah kelompok orang Cina dan Arab dan dalam perkembangannya juga digunakan oleh anak muda Madura perkotaan untuk menambah keakraban maupun dimensi kegaulan sesamanya termasuk, mempererat hubungan dengan kelompok orang-orang Cina dan Arab di daerahnya.

Di daerah perkotaan, terutama dalam situasi formal atau di lingkungan penanda kemodernan, seperti sekolah, kampus, ruang rapat, pagelaran musik, dan lain sebagainya, orang Madura cenderung memakai bahasa Indonesia yang diselipi juga beberapa kosakata Madura. Bahasa Indonesia tersebut digunakan selain cerminan bahasa nasional juga sebagai bentuk menghormati jasa besar Moh. Tabrani, putra daerah Madura yang telah 'berdarah-darah' berjuang memasukkan bahasa Indonesia sebagai bahasa persatuan pada peristiwa sumpah pemuda. Sekalipun begitu, pada kongres bahasa Madura yang pertama terungkap kekhawatiran akan punahnya identitas kebahasaan orang Madura yang lekat dengan nuansa estetis, pengalaman, dan penghayatan hidup kesehariannya. Pesatnya teknologi komunikasi yang berkontribusi menambah daya perjalanan globalisasi di pulau Madura secara perlahan mengikis penggunaan bahasa Madura yang terutama sekali di kalangan generasi mudanya karena langkanya pengantar bahasa Madura pada program televisi, radio, hingga media cetak (Rifai, 2008). Bahasa Madura sebagai bagian identitas budaya Madura cenderung dianggap pelengkap kebanyolan saja dan memicu kelucuan dalam program media massa (Abdullah, 2011). Intensitas penggunaan bahasa Indonesia yang terbilang terlampau besar dalam mengantarkan pelajaran di lembaga pendidikan, selain juga, perasaan malu orang Madura di perantauan atau daerah urban agar menggunakan bahasa Madura dengan sesama etniknya, ikut menyumbang rapuhnya kekuatan bahasa Madura di hadapan bahasa nasional dan bahasa etnik lain yang cenderung dominan (Kusnadi, 2008). Generasi muda Madura yang lebih banyak menyerap bahasa Indonesia dan bahasa asing kadangkala kebingungan, bahkan juga, sedikit sungkan menggunakan bahasa Madura tatkala berhadapan dengan orang yang lebih tua atau memasuki wilayah pelayanan publik di daerahnya. Setidaknya, masih beruntung di antara mereka masih mengetahui perbedaan kata penunjuk diri di dalam tingkatan bahasa Madura dan pengunaannya dalam kehidupan sehari-harinya.

\section{Rute Kultural Musik Populer di Madura}

Sejak abad sembilan belas, tipikal masyarakat Madura tergolong masyarakat berubah, dan perubahan tersebut sekurangkurangnya terkait tiga aspek (Kuntowijoyo, 1989: 34-43). Pertama, kepemilikan tanah yang tidak lagi terpusat di tangan keluarga kerajaan. Kedua, pembukaan lahan pertanian baru di luar Madura mendorong tradisi merantau orang Madura. Ketiga, maraknya industri garam di Sampang, Pamekasan, dan Sumenep. Selain ketiga hal itu, sebagai upaya mengantisipasi munculnya kembali perlawanan orang Madura yang heroik sebagaimana menimpa Mataram pada peristiwa perang Trunojoyo, maka, permulaan 1900-an di pulau Madura oleh Belanda ditempatkan residen Madura di Pamekasan, asisten residen di Bangkalan, seorang kontrolir dan beberapa opsir Belanda di Bangkalan, Pamekasan, dan Sumenep. Seorang residen Madura mengatakan berdasarkan informasi bupati bawahannya bahwa pada masa-masa itu hutan jati di Madura banyak digunduli atas perintah kontrolir Belanda untuk dijual atau dipakai sendiri (Hadiwidjojo, 1959). Pada zaman Jepang, bupati Pamekasan, R.A.A Abd. Aziz, terbunuh oleh pasukan Jepang karena menolak romusha, tetapi dia berkontribusi besar dalam berdirinya sekolah MULO (sekarang SMPN 1 Pamekasan), sekolah menengah dan satu-satunya di Madura, atas biayanya sendiri (Djojoprajitno, 2005). Setelah negara Madura berakhir pada waktu 04 Maret 1950 sebagai lonceng kematian negara boneka Belanda yang telah berdiri sekitar dua tahun lamanya, residen Madura R.I pertama dan satu-satunya, R. Soenarto Hadiwidjojo, merelakan halaman belakang kantornya yang berada di jantung kota Pamekasan menjadi SMA pertama di Madura (kini, SMAN 1 Pamekasan) bahkan, dia menyediakan waktu khusus agar membantu mengajar di sana (Djojoprajitno, 1988). Sistem persekolahan model barat ini tampaknya sejak semula menuai dilema karena selain bertujuan memperkaya ilmu pengetahuan dan memberantas kebodohan, juga mendidik kaum pribumi menjadi pewaris birokrasi modern kolonial (Kartodirjo, 2014: 406).

Beriringan dengan berdirinya pusat-pusat pendidikan modern itu, televisi dan gedung bioskop juga merambah pulau Madura (Rifai, 1993: 85). Dibandingkan Slovenia yang kala itu baru saja tumbuh media massa seperti radio (Berber-Kersovan, 1989), atau di negeri Arab yang televisi mulai berkembang pesat pada era 1970-an (Hammond, 2005), tentu saja Madura terbilang selangkah lebih maju dan modern dari keduanya, sekalipun diakui Madura masih tertinggal setengah abad dari Amerika. Kelahiran masyarakat kontemporer ditandai oleh abad masyarakat sinematik yang mengkapitalisasi tatapan kamera sebagai metode mengkreasikan dan mendokumentasikan realitas telah dimulai sejak permulaan 1900-an di Amerika (Denzin, 1995: 2). Adegan-adegan media audio-visual ini berdampak pada menguatnya kerja imajinasi sebagai pembentuk gambaran subjektivitas modern yang kosmopolitan, glamor, dan sarat kebaruan sehingga mengguncang, merongrong bahkan, berusaha memutuskan hubungan dengan sesuatu hal masa silamnya (Appadurai, 1996: 3). Dari sana rute budaya rock dimulai sebagaimana pandangan Clifford (1997: 2) bahwa rute mengasumsikan adanya pergerakan, perjalanan dan kontak dengan situs-situs krusial sebagai suatu persinggahan sementara bagi kelangsungan proses modernitas yang belum selesai (unfinished modernity) serta berlanjut 
pada upaya merajut makna dan pewarisan budaya berbeda untuk mendapatkan dukungan dan pengakuan dari orang-orang sekitar. Fenomena pergerakan kultural ini adalah ritus peralihan (rites of passage) subjek lokal yang rapuh yang sebelumnya terbentuk atas dasar kedekatan ekologis dan rasa bertetanggaan (neighborhoods) seperti, hubungan kekerabatan, pertemanan, dan permusuhan yang akan memicu ritual deliberatif penampilan, representasional, dan tindakan (Appadurai, 1996: 179-180). Pada konteks ini, dunia imajinasi kelompok musisi populer di Madura mengalami peristiwa keterputusan dengan musik etniknya berdasarkan ruang lingkup teknologi (technoscape) musikalnya yang dari segi mekanisme peralatannya berbeda dari peralatan musik tradisionalnya. Ruang lingkup teknologi merupakan konfigurasi global, karena teknologi, baik itu berskala rendah maupun tinggi, mekanikal maupun informasional, memiliki kemampuan mencairkan dan menembus batas-batas yang tampak kaku serta baku sebelumnya sehingga, keberadaan teknologi tersebut menjadikannya objek prestisius bagi mereka yang memiliki serta mahir menggunakannya (Appadurai, 1996 dan 2006).

Teknologi musikal sebagaimana gagasan Schafer (1977) secara lebih spesifik menyebutnya ruang lingkup teknologi bebunyian (soundscape) yang menciptakan perubahan kualitas dan intensitas bebunyian musikal di masa lalunya yang terbatas dan alamiah menjadi lebih baru, menghasilkan suara sonikal, hingga menjangkau pendengaran orang-orang secara lebih luas. Teknologi bebunyian sonikal tersebut sering kita kenal sebagai musik elektronikal, suatu seni yang mengawinkan teknologi dan imajinasi manusia, sehingga menghasilkan suatu fenomena suara yang mensistesiskan beragam warna suara atau timbre kekhasan instrumen musikal modern berkat keberadaan rangkaian teknologi amplitude, frekuensi, dan durasi mengeraskan, mengharmoniskan, bahkan memperpanjang jangkauan sistem bebunyian musik populer (Holmes, 2016). Ledakan anak-anak muda yang sering disebut generasi baby boomer yang lahir di antara era 1940-1960-an merupakan dekade kehidupan anak-anak muda rock ' $n$ ' roll, suatu gambaran eksistensi diri yang mengalami perubahan sosial mengenai situasi dan individualitas elektronikal (e-self), pendewasaan diri layaknya orang tua (the self as parent), dirinya bisa dipercaya (the self as believer), mampu mengatur waktu (the self as timekeeper), memiliki kemampuan politik (the self as political actor), dipenuhi bungabunga cinta (the self as lover), dan lain sebagainya (Kotarba, 2013). Rock ' $\mathrm{n}$ ' roll sebagai bagian musik populer yang mengguncang musik dunia sejak era 1950-an, selain bercirikan orientasinya pada selera anak-anak muda dan menambah kegunaannya bagi aktivitas dansa, ia juga diarahkan pemain gitar yang bertipikal amplifayed dengan menonjolkan ritem blues, jazz, dan country (Kotarba dan Vannini, 2009; Kotarba, 2013). Kelahiran rock 'n' roll yang suara musiknya membuat keributan di sekitarnya ditandai kemunculan dua gitar elektrik legendaris, Gibson dan Fender, di mana gitar Gibson digunakan pertama kalinya oleh band-band rock ' $n$ ' roll tersohor dari Inggris seperti, The Rolling Stone dan The Beatles, sementara, gitar Fender digunakan oleh Beach Boy, band rock ' $n$ ' roll Amerika, dan semakin populer berkat gitaris Jimmy Hendrix, sehingga kedua gitar produksi Amerika yang harganya selangit ini menjadi rivalitas tersengit pada periode sejarah rock ' $n$ ' roll di dunia, serta menjadi inspirasi kelahiran produk-produk gitar elektrik dan penguat suara (amplifier) pada masa-masa selanjutnya (Port, 2019). 1) Band Empat Bayangan: Sang Pelopor Musik Populer di Madura

Gedung bioskop termegah, terbanyak, dan terlengkap berada di Pamekasan, letaknya tidak jauh dari kantor residen Madura. Gedung bioskop Irama, misalnya, tergolong gedung bioskop tertua di Madura, dibangun pada dekade awal 50-an, terletak sekitar 10 meter di sisi timur kantor karesidenan Madura. Kira-kira setahun berikutnya, disusul berdirinya gedung bioskop Benhil di sayap selatannya, sekitar 20 meter dari kantor karesidenan Madura. Setelah itu, bioskop Maduratna juga hadir menyapa Madura, terletak sekitar 15 meter di sayap barat gedung karesidenan. Hanya gedung bioskop Benhil atau Jaya yang pemiliknya peranakan Cina, sisanya adalah milik keturunan Arab, kendati semuanya dikelola dan dijaga ketat oleh orang-orang pribumi Madura. Melalui gedung bioskop inilah musik populer menggema dan menyebar hingga penjuru pulau Madura. Empat Bayangan boleh jadi merupakan band populer pertama yang berhasil menyebarluaskan rock di Madura dan terbentuk beberapa bulan saja sebelum band rock AKA asal Surabaya resmi menggema di pertengahan dekade 60-an guna menyemarakkan belantika musik populer Indonesia dari panggung ke panggung. Kabarnya, seorang pemain gitar Empat Bayangan ini pernah rekan sekerja dengan salah satu anggota band Koes Plus dalam bidang industri tebu di Jember, sebelum akhirnya keduanya kembali menggeluti bidang musik populer di daerahnya masing-masing. Adalah figur Bill Halley, pemusik rock and roll yang tampil dalam film Rock Around The Clock yang diputar di bioskop-bioskop memukau anak anak muda di Indonesia sehingga menginspirasi mereka menyukai budaya populer dan semakin keranjingan membentuk band musik populer (Sakrie, 2015: 18). Gejala tumbuhnya semangat mencintai budaya maupun musik kebarat-baratan ini menyulut presiden Soekarno melarang keras kawula muda menggalakkan musik 'ngak-ngik-ngok' di mana-mana. Band Koes Plus menjadi salah satu korbannya karena pada saat mereka mengisi pesta ulang tahun di Patamburan Jakarta, atap rumah tuan rumahnya dilempari batu dan dari luar rumah itu sekelompok massa berteriak, "ganyang ngak-ngik-ngok" (Theodore, 2013: 21). Presiden Soekarno juga mengundang Jack Lesmana, Idris Sardi, dan Bing Slamet membuat lagu dan album Mari Bersuka Ria yang dirilis resmi sekitar awal April 1965 dengan dalih mengenalkan karakter musik nusantara beriramakan lenso, sebuah alunan musik melayu yang menggabungkan seni tepukan tangan, okolele, tabuhan bass, sedikit variasi gamelan, yang jika dimainkan mirip musik keroncong bertempo sedang. Suatu keanehan karena lagu dan album ini direkam melalui rekaman berlabel Irama. Padahal, label Irama menggunakan peralatan rekaman dan susunan katalog musikalnya yang diadaptasi dari barat (Yampolsky, 2013: 336). Walaupun demikian, keberadaan musik rock pada zaman orde lama itu menjadi petanda awal terbukanya rute rock di Madura, dimulai dari band rock Empat Bayangan, band rock legendaris dari Pamekasan.

Satu bulan sebelum band rock legendaris AKA (Apotek Kaliasin) asal Surabaya resmi terbentuk, pada April 1967 di kota Pamekasan Madura lahir band 4 Bayangan (4B). Melalui tangan dingin Darsono Kusuma (kelahiran 1933 dan meninggal tahun 1993) yang dikenal oleh masyarakat sekitarnya dengan panggilan "Pak Darsono", dia berhasil mengumpulkan (makompol) 4 
anak muda handal pada bidang 'permusikan’ (bén-bénan). Mereka adalah Suk (bass), kakaknya Suk, Yoyok (drum), Edi Manupati (gitar), dan Junaidi Boy (vokal). Semua anak muda ini memiliki kemampuan memainkan semua alat musik band dan tradisional. Sebelum 4B terbentuk, telah terdapat tiga band yang mengandalkan instrumen gitar dengan membawakan lagu jazz, keroncongan, dan rock melayu saat mereka latihan. Tiga band tersebut antara lain Budi S Combo, Zakaria, dan Quwinta Nada. Para anggotanya biasa berkumpul (pol-kompol) untuk latihan band di rumah pengusaha pabrik es, Eskimo, milik Cong In. Budi Suryaman (Budi S) yang kabarnya masih bagian keluarga Cina tersebut dikenal gitaris handal di Madura. Budi S. Combo atau populer dengan julukan band "8 Tangan" (karena beranggotakan empat orang personel) ini salah satu anggotanya adalah Suk (kelahiran 1951).

Suk banyak belajar gitar kepada Budi, sekalipun secara usia keduanya tidak terpaut jauh. Tetapi, Budi dianggap lebih berwawasan luas karena terbiasa pergi ke Surabaya untuk menyaksikan pertunjukan musik atau membeli karya musik yang menjadi bahan pembicaraan kawan-kawannya di sela-sela membeli pasokan barang dagangan untuk usaha keluarganya di Madura. Menurutnya, Budi adalah pemain musik melodius yang tergila-gila pada gaya musik rakyat (folk rock) Bob Dylan asal Amerika dan rock keroncongan (indorock) Tielman Brother (kelompok musik anak muda dari Indonesia Timur yang kala itu tersohor di Surabaya). Lagu andalannya adalah lagu Bob Dylan berjudul "Master of War" yang dimainkannya bersolo gitar ditemani 'biduan' harmonika dan instrumental Tielman Brother, "Black Eyes Rock” (perpaduan antara keroncong dan rock) yang dibawakannya ketika latihan bersama bandnya. Di rumah Cong In tempat berkumpulnya anak-anak band berlatih musik hampir setiap hari. Letak rumahnya di pusat kota, di pinggir jalan utama antar kota di pulau Madura, berhalaman luas, dan berpagar dinding terbuka membuatnya mudah ditonton banyak orang yang lewat di sana. Kini, rumah itu tertutup rapat oleh bangunan tembok raksasa, berlokasi di ujung barat jalan Niaga, pusat perdagangan kuliner Madura di sepanjang perkampung pecinan (pong cènah) bersejarah, dan jaraknya berkisar 25 meter sebelah selatan dari monumen arek lancor, pusat kota Pamekasan. Band-band yang terbentuk di sana memang tidak bertahan lama, hitungan bulan saja, kendati demikian dari sanalah setidaknya sejumlah anak band mengembangkan minat bermusiknya di masa-masa selanjutnya. Di antara berbagai alasan yang membuat band di sana tidak bertahan lama adalah perkara arebbu' téngka (melukai perasaan) anak-anak muda yang sedang senang dan giat-giatnya belajar musik rock. Menurut Suk:

"Pertemanan kami dengan orang-orang Cina sangat akrab sekali, termasuk dengan Budi. Budi memang orang baik, senang berteman dengan siapa saja. Dia sangat loyal dan royal dengan memberi keleluasaan bagi teman-temannya yang berniat belajar atau sekedar bermain musik di sana. Karena salah satu orang tuanya sangat cerewet (crémi) sehingga, kata-katanya melukai perasaan kami hampir setiap hari, maka satu persatu menjauh. Mungkin saja kegiatan musik kami tidak menguntungkan baginya. Nyatanya, tidak hanya Saya, bahkan, Budi juga pergi meninggalkan rumahnya. Kabarnya, dia merantau ke Jakarta dan menjadi musisi cafe dan hotel terkemuka. Sejak kepergiannya, band-band yang pernah terbentuk berkat jasa-jasanya akhirnya bubar juga. Beberapa anggota band tersebut Saya coba ajak membentuk band baru tanpa memberitahukan anggota lainnya"

Sebelum membanting setir ke dunia permusikan anak-anak band, Pak Darsono masih senang memfasilitasi anak-anak muda menggeluti kesenian dan musik tradisional, seperti tari, topeng dalang, dan seronénan. Kakak beradik, Yoyok dan Suk, yang masih keluarga dekat (bhâleh semmak) Pak Darsono juga ikut terlibat di kegiatan seni tradisional tersebut. Yoyok membantu menabuh gendang (ghendhăng) sementara, Suk pemain gamelan (klénangan). Ada dua karya seni tradisional yang tampak khas di kalangan mereka. Yakni, tari Maja/Maya dan topeng dalang Purba. Dua kesenian ini hanya ada di lingkungan masyarakat Purba. Sekalipun letak rumah Pak Darsono di jalan Seruni nomor 3, secara geografis masih tercakup klasifikasi masyarakat Purba. Menurut sejarah lisan yang berkembang Purba merupakan sosok seniman, pencinta kesenian rakyat, dan petinggi kerajaan dari trah Majapahit yang tinggal menetap di sana. Munculnya kesenian topeng dalang Purba dan tari Maja tidak bisa lepas dari perannya. Kesenian inilah yang dikembangkan oleh masyarakat Purba. Hampir setiap malam kelompok kesenian tradisional Madura binaan Pak Darsono rupanya tidak pernah absen memainkan topeng dalang dan tari Maja, baik ketika latihan rutin maupun persiapan memenuhi undangan pementasan mengisi acara hiburan manten/pernikahan (mantan), pertemuan formal instansi pemerintahan, serta pentas kesenian tingkat persekolahan. Dari kegiatan musik tradisional itulah dasar-dasar bermusik mereka dapatkan. Mereka menganggap tidak menemukan kesulitan ketika akhirnya berpindah haluan menggeluti band karena hanya mengubah posisi bermain dan peralatan saja.

Kejenuhan yang memuncak diperkuat dengan ejekan teman-teman sebayanya sebagai anak muda 'ketinggalan zaman' (nahmakonah) membuat Suk dan Yoyok merasa tidak betah lagi bermain seni musik tradisional. Waktunya tersita bersama temanteman pemain band dan jarang berkumpul lagi di rumah Pak Darsono. Mereka berdua semakin semangat menggeluti musik band setelah dua gedung bioskop Irama (milik pengusaha arab) dan Bhenghil atau Jaya (milik pengusaha Cina) yang tak jauh dari tempat tinggal mereka silih berganti menayangkan film populer bergenre rock $n$ ' roll yang berjudul "Rock Around the Clock". Mereka memang tidak menonton langsung, hanya menguping dan mengintip adegan filmnya. Gedung bioskop yang dibangun sejak dekade 50-an itu menjadi satu-satunya sentra hiburan di pulau Madura, terlebih lagi Pamekasan, jauh sebelum kota lain di pulau Madura memiliki gedung bioskop. Anak-anak muda dari berbagai penjuru kota mencari angin segar dan melepaskan kepenatan dengan cara duduk menempel bergerombol di dinding terluar gedung bioskop itu. Sembari menikmati kacang goreng sambil membicarakan topik apa saja, pandangan mereka cekatan memperhatikan keluar masuknya para penonton bioskop, dan sesekali pendengarannya sigap menyergap beberapa adegan musikal dari film yang diputar dalam gedung. Gedung bioskop itu tidak sepenuhnya tertutup rapat. Di bagian pintu masuknya sengaja dibuka, di sisi pinggir gedung terdapat beberapa pintu dan celah-celah udara di atasnya supaya penontonnya tidak terasa pengap di dalam ruangan. Pemutaran film hanya dilakukan malam hari saja agar tidak mengganggu aktifitas kerja dan waktu sekolah siswa, termasuk mengurangi 
udara panas yang menyengat di pulau Madura. Pada waktu lagu "Rock Around the Clock" terbawa gelombang angin ke luar melewati celah-celah gedung hingga terdengar jelas bunyi musiknya, Suk dan kawannya (ca-kancanah) mulai khusuk mendengarkan musik jenis baru yang belum pernah dikenali sebelumnya. Tubuhnya tiba-tiba bergerak mengikuti dentuman irama musik rock $n$ ' roll yang riang gembira dan menggoda siapa saja yang terlanjur menikmatinya. Adegan film musikal itu membuat sekujur tubuhnya berjingkrak-jingkrak sebisanya. Secepat kilat mereka mendekati gedung bioskop Irama dan melakukan tindakan menonton rahasia dari balik pintu dan lubang angin yang terbuka. Serasa menemukan energi hidup baru pada malam itu, esok harinya Suk menemui temannya yang memiliki gitar akustik untuk belajar memainkan musik rock $n$ ' roll yang telah menancap kuat dalam benaknya.

Sekalipun Suk dan Yoyok pernah berada satu perkumpulan di kelompok seni musik tradisional, mereka berdua saling bersaing (so-mosoan) di dunia band. Terbukti pada saat Pak Darsono telah kehilangan banyak pemain seni orkestra musik tradisional Madura dan beralih ke dunia musik anak muda yang mulai merambah di kota itu dengan membeli peralatan band lengkap dari Surabaya, ternyata Suk tidak ingin bergabung dengan kakaknya yang lebih dulu direkrut sebagai penabuh drum. Karena ajakan temannya, dia lebih memilih menjadi personel band Delicious sebagai pemain melodi sekaligus pengajar anggota lainnya yang semuanya perempuan. Karena dibujuk (è yoman) pamannya untuk bergabung memperkuat band binaan Pak Darsono, dia terpaksa bergabung satu band dengan Yoyok. Band yang belum lengkap itu membuat Suk mengajak beberapa kawannya yang sebelumnya pernah ikut bermain di band 8 tangan untuk bergabung dengannya. Direkrutlah Edi Manupati dan Junaidi (mantan juara satu lomba menyanyi keroncong tingkat Jawa Timur). Keduanya keturunan Sumenep yang pindah ke Pamekasan untuk menempuh jenjang pendidikan lebih tinggi karena satu-satunya sekolah menengah dan terlengkap di Madura hanya berada di Pamekasan. Atas peran Suk juga nama 4B disodorkan kepada Pak Darsono. Terpilihnya nama band 4B karena mereka merasa masih berhutang budi pada 8 tangan sehingga, untuk mengingat jasa-jasanya dibuatlah replikasinya. Maka, terbesitlah ide menggunakan nama 4 bayangan yang berarti 4 orang sebagai cerminan dari band 8 tangan. Angka 4 dipilih karena mewakili konsep 8 tangan (1 orang dua tangan). Nama 4B langsung disetujui Pak Darsono. Angka 4 adalah angka favoritnya. Hidup orang Madura dikelilingi angka 4 setidaknya terlihat dari jumlah daerah di Madura (Bangkalan, Sampang, Pamekasan, dan Sumenep). Arah mata angin utama juga berjumlah 4: barat, timur, selatan, dan utara. Angka 4 juga termasuk bagian dasar musikal, seperti bhirama. Kehidupan pribadi Pak Darsono juga kental dengan angka 4 . Anaknya berjumlah 4. Keempat-empatnya perempuan semua. Menurut pengakuan putri sulungnya, Anik Darsono (kelahiran 1962):

"Entah kenapa bapak menyukai sekali dengan angka 4. Anaknya saja empat, perempuan semua. Nama depan keempat anaknya berisi konsonan huruf A. Anik, Anna, Atik, dan Yanti. Bentuk rumahnya juga mirip angka 4. Di bagian sisi kanan rumah menjorok lurus ke depan melebihi sebelah kiri bangunan. Sebelah kiri bangunan tampak sedikit menyerong dan ujungnya melengkung ke dalam lalu lurus merapat ke sisi kanannya. Tetapi, nama band 4 bayangan barangkali berkaitan erat dengan keempat anaknya yang perempuan semua"

Pada dekade 60-an, memang band musik terkenal kecenderungannya terdiri dari empat orang karena akan mudah dikenal daripada band dengan memiliki banyak anggota. Beberapa di antaranya, Koes Bersaudara, AKA, Panbers bersaudara, Tielman Brothers, termasuk band berkelas internasional: The Beatles dan The Rolling Stones. Gaya bermusik mereka berpengaruh terhadap formasi band 4B. Tidak tanggung-tanggung, sebagai kontraktor sukses dan golongan orang kaya (réng soghi) di pulau Madura, Pak Darsono berusaha membeli peralatan musiknya sebisa mungkin menyamai band-band bereputasi dalam dan luar negeri. Merek gitar Tesco, Fender, hingga Gibson dipesan langsung dari mancanegara. Seperangkat teknologi bebunyiannya (sound system) bermerek Fender dan Marshall. Instrumen organ andalannya bermerek Farfisa dilengkapi organ merek lainnya yang tidak kalah hebatnya, Hammonds. Dua jenis organ ini kerapkali digunakan band selevel band Deep Purple, Led Zeppelin, dan The Beatles. Dengan peralatan yang harganya selangit itu, sebanding harga tanah ratusan hektar, tentu saja kualitas suara yang dihasilkan tiada bandingannya untuk sekelas band di Madura, terlebih lagi, di Surabaya. Bahkan, peralatan band 4B dalam setahun bisa berganti 2 hingga 3 kali agar mengikuti model perangkat band yang terbaru. Salah seorang penggemar yang pernah menyaksikan 4B di kota Bangkalan penuh keheranan dan komentarnya sedikit berlebihan. Katanya, seandainya semua perlengkapan serta peralatan band 4B itu dijual kemudian uangnya disedekahkan, maka bisa mensejahterakan seperempat penduduk Madura. 


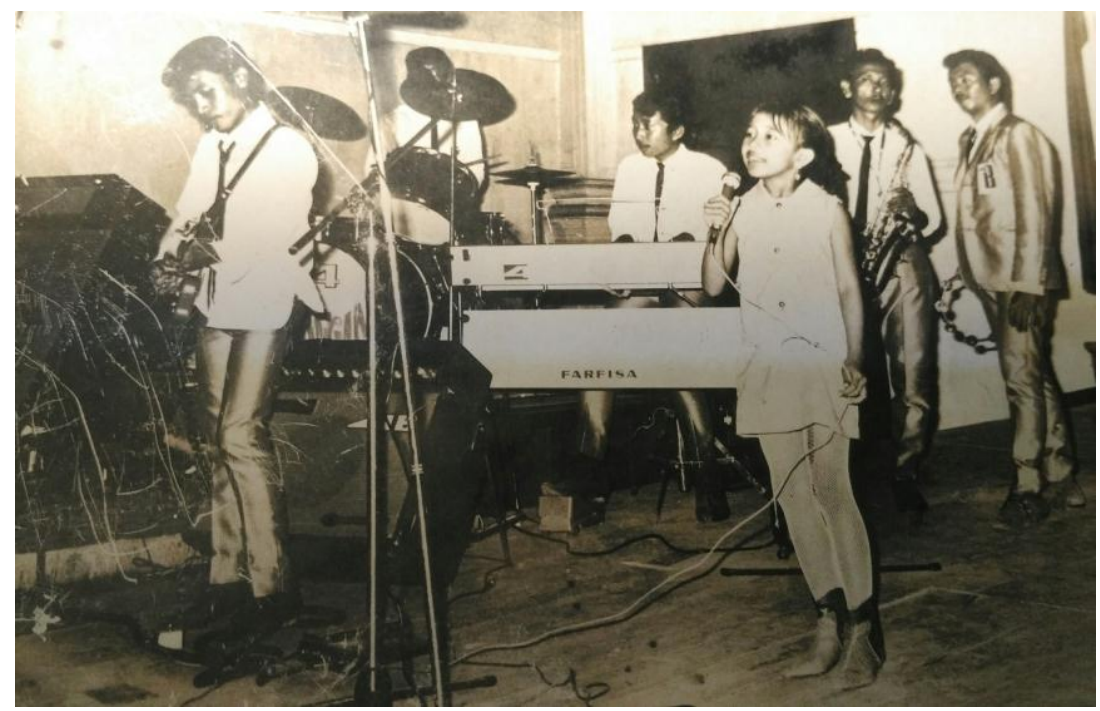

Gambar 2. Empat Bayangan dan Penyanyi Cilik Andalannya, Anik "Si Boncel” (Foto: Ara)

Para personel AKA silih berganti pernah bertandang ke rumah Pak Darsono. Dengan jaringan bisnisnya yang luas dan dekat dengan orang-orang partai atau pemerintahan, bukan hal yang mustahil baginya mendatangkan musisi ternama untuk datang ke Pamekasan. Secara spesial mereka diminta oleh Pak Darsono untuk melatih musik personel 4B. Saat memiliki waktu luang, teknisi dan pengatur audio AKA yang disebut "sé tekkog" (si bungkuk) sebagai panggilan akrab anggota 4B juga rutin datang bersama personel lainnya. Selain mengajari cara menyetel perangkat bebunyian band yang tepat, dia juga bertugas membeli dan merakit seperangkat audio 4B. Sebagai tamu mereka diberi pelayanan istimewa, bahkan, dipesankan kamar khusus di hotel Madura (sekarang bernama hotel Garuda), satu-satunya hotel terbaik di Madura, tempat menginapnya para pejabat, pengusaha, dan artis ibu kota yang datang ke Pamekasan. Mereka diantar pulang pergi mengendarai mobil pribadi Pak Darsono. Lama-lama hubungan AKA dan 4B berjalan layaknya saudara. Melalui Pak Darsono band AKA seringkali diberikan pekerjaan mengisi acara di Madura, baik peresmian bangunan jembatan dan pembukaan jalan-jalan baru, pernikahan keluarga rekanan bisnis, atau bintang tamu acara konser kecil-kecilan setiap malam minggu. Pada waktu AKA pertama kali datang dan melihat langsung peralatan band 4B, mereka terkejut, terkaget-kaget, serta merasa keheranan seheran penggemar 4B di Bangkalan itu. Mereka seakan menemukan tambang emas di tengah padang pasir yang tandus, karena tak menyangka jika di Madura, kota kecil tepat di tengah pulaunya, yang letaknya jauh dari Surabaya, tersembunyi band anak muda dengan kemampuan musikal di atas ratarata plus dukungan fasilitas peralatan musikal berkelas dunia.

Tidak hanya itu, Pak Darsono juga menyediakan empat mobil khusus untuk kegiatan manggung 4B. Satu mobil untuk para personel band. Satu mobil bagi pemain undangan. Dua mobil lainnya difungsikan mengangkut segala peralatan band. Masingmasing personel band juga diberikan pakaian jas empat warna lengkap dengan kemeja, dasi, dan sepatunya. Semua seragam pentas ini dipesan langsung dari toko-toko terbaik di kota Surabaya. 4B menampilkan diri mereka seakan memperkokoh citra band berkelas dunia, modern, dan kosmopolitan di pulau Madura. Setiap latihan para personel band 4B dijemput menggunakan mobil ibarat artis yang datang ke daerah-daerah. Ini juga berlaku bagi personel tetap dan undangan yang berasal dari luar Pamekasan. 4B menjadi arus utama pertemuan dan berkumpulnya musisi hebat dari penjuru Madura. Para penyanyi perempuan yang diajak tampil sewaktu 4B diundang mengisi acara hiburan dari kota hingga pelosok Madura adalah penyanyi unggulan dan pernah juara di ajang menyanyi tingkat sekolah atau daerah. Pada perkembangannya 4B bukan sekedar band musik amatiran melainkan menjelma sebagai rumah manajemen dan produksi artis lokal. Para anggota, baik tetap maupun undangan sudah menganggap 4B sebagai rumah keduanya. Sehari-harinya mereka yang tergabung di dalam 4B diberikan jatah makan, rokok, uang jajan, dan terkadang pekerjaan sampingan membantu kelancaran proyek bisnis Pak Darsono, seperti pengawasan proyek konstruksi, mebel, persewaan perangkat sistem audio, peragaan busana, catering, alat angkut (truk, pick up, dan mobil mewah), dan lain sebagainya. Seusai mengisi acara pernikahan, setiap pemainnya diberikan uang tambahan sekitar Rp. 3000 - Rp. 5000 , jumlah uang yang sangat besar pada masa-masa itu karena sepiring nasi dan sebungkus rokok paling mahal harganya Rp. 200. Para pemain undangan 4B jumlahnya bisa mencapai belasan. Mereka terbagi ke dalam peran-peran penting sebagai peniup klarinet dan seksofon, penyanyi utama dan pendamping, pemain organ ataupun piano, pembawa acara (MC), serta teknisi plus pengatur audio.

Kira-kira tidak sampai setahun setelah 4B terbentuk Pak Darsono juga merekrut para anggota band yang semua anggotanya perempuan. Band perempuan itu dinamakan Majabena. Nama "Maja" diambilnya dari jenis tarian peninggalan seniman plus tokoh kerajaan bernama Purba. Sedangkan, "bena" merupakan singkatan dari "benar-benar Madura". Majabena lantas secara spontan oleh para penonton mereka diartikan sebagai "Madura jang benar-benar artis" karena penyanyinya malang melintang di kejuaraan lomba menyanyi. Anik (anak bungsu Pak Darsono) dan Yul Rusli kerabat dekatnya memberikan kejutan di setiap penampilan 4B dan Majabena karena mereka tergolong vokalis cilik yang mampu menyanyikan lagu-lagu orang dewasa hampir tanpa kesalahan. Tidak ada band lain selain 4B dan Majabena yang memiliki penyanyi cilik seusia anak sekolah dasar. Sejak 
semula penyanyi cilik ini diajak pentas, selain melatih keberanian mereka tampil di depan umum, juga mengasah bakat bernyanyinya dan dipersiapkan menjadi generasi penerus. Keduanya memiliki karakter vokal yang berbeda dan saling melengkapi. Yul terkenal dengan karakter vokal yang tinggi, sedangkan karakter vokal Anik bertipikal halus dan merdu. Gaya pakaian mereka juga persis penyanyi rock dewasa. Bersepatu boot warna hitam, terkadang putih, diselingi sepatu kulit pendekar yang tali-talinya melilit di antara kedua kaki, atasannya bervariasi putih dan hitam berlengan pendek dengan aksesoris kancing metalik, kedua tangannya ditutupi sarung tangan kulit hingga sebatas siku, serta gaya rambut depannya terbelah sebatas mata dan bagian belakangnya ditata sedemikian rupa sehingga terkesan cewek tomboi mirip penyanyi band rock Pretty Sister. Selain mereka berdua, panabuh drum Majabena juga drumer cilik dan keponakan Suk (penabuh bass 4B). Kabarnya, dia pernah ditawari menjadi penabuh drum pendamping band rock perempuan legendaris asal Surabaya, Dara Puspita, tetapi, ditentang keras bapaknya. Akhirnya, drumer cilik Majabena ini setelah lulus sekolah menjadi penabuh drum dan gendang orkes dangdut terkenal, Ken Dedes, dan pada beberapa kesempatan juga pernah berduet maut dengan band dangdut Rhoma Irama, Soneta.

Majabena sempat menggemparkan dunia permusikan Madura tatkala mereka menjadi band pendamping konser Pretty Sister saat tampil di gedung bioskop Irama Pamekasan pada permulaan dekade 70-an. Bersama 4B yang lebih dahulu tersohor di dunia band rock Madura, Majabena dengan penyanyi ciliknya berhasil tampil menyihir ribuan penontonnya yang saling berdesakan sebelum konser dimulai. Masa-masa ini semua konser atau pementasan musik di Pamekasan digelar secara rutin setiap malam minggu. Walaupun digelar malam hari, gedung bioskop Irama dalam sekejap menjadi lautan manusia dari segala jenis usia, tua dan muda, dari latar daerah, barat dan timur pulau Madura, semuanya tumpah ruah seperti haus hiburan musik. Kapasitas kursi gedung yang diperkiran hanya mampu menampung 1000-1500 orang dari lantai dasar hingga lantai atasnya justru di luar perkiraan. Semua tiket seharga tiga ratus rupiah ludes terjual. Mereka yang kehabisan tiket rela membayar dua kali lipatnya walaupun harus duduk di lantai bersila di antara kursi penonton atau berhimpitan di bawah panggung. Selain penjual kacang, para tukang becak merupakan pihak yang turut mendapat keuntungan berlimpah dengan adanya acara konser musik rock tersebut. Masa-masa itu becak merupakan golongan kendaraan umum yang dianggap sangat mewah. Hanya golongan orang kaya yang biasa menggunakan jasa tukang becak sementara itu, mereka yang pas-pasan, apalagi, kaum tidak berpunya (réng mlarat), lebih memilih berjalan kaki dari satu tempat ke tempat lainnya. Para tukang becak juga terbiasa menjemput dan mengantarkan para penumpangnya dari kota Pamekasan ke kota Sampang yang jarakanya sekitar $30 \mathrm{Km}$. Tukang becak ini diuntungkan karena kereta api yang biasa berhenti di depan gedung Irama setiap pagi hari memang tidak pernah beroperasi pada malam hari. Orang-orang yang hendak menonton konser tetapi tidak mampu membeli tiket biasanya akan mengintai di antara celah pintu masuk gedung Irama. Sebagian orang lainnya secara suka rela membentuk susunan tangga manusia silih berganti agar leluasa mengintip dari balik lubang-lubang ventilisi udara gedung Irama yang tingginya mencapai empat meter lebih. Saksi sejarah, mantan penilik kebudayaan sekaligus pelaku seni musik tradisional Madura, Hafid (kelahiran 1937), mengatakan bahwa:

"Jika di luar Madura kita akrab dengan band rock AKA, Dara Puspita, dan Pretty Sister yang semuanya ini berpusat di Surabaya, maka di Madura band yang tidak kalah hebat dari mereka berada di Pamekasan, yakni, 4 Bayangan dan Majabena. Awal mula 4 Bayangan dan Majabena terkenal karena sering mengisi pesta perkawinan dari kota ke kota, dari kampung ke kampung, baik di Madura, Surabaya, dan sekitarnya. Tetapi, ketika mereka konser bersama di gedung bioskop Irama dengan mendatangkan Pretty Sister sebagai bintang tamunya, penonton dari banyak tempat berduyun-duyun datang melihat. Di dalam gedung nyaris tak bisa mendapat udara segar secara sempurna karena penuh sesak dengan penonton yang jumlahnya melebihi kapasitas. Di antara lubang angin gedung silih berganti terlihat kepala-kepala manusia berjejeran tanpa sekujur badan. Kehebatan konser mereka ini boleh dibilang menggeser kedudukan lodruk yang saat dekade 50-an menjadi hiburan primadona orang Madura dan mahal harganya. Jika lodruk sekali tanggap kira-kira mencapai harga kisaran jutaan rupiah dengan perlengkapan dan peralatan pentas yang jumlahnya berlipat-lipat dan memakan banyak tempat, band 4 Bayangan dan Majabena bisa tampil di atas panggung berukuran sederhana, di gang-gang sempit perkampungan sekalipun, dengan peralatan musik modern yang jauh lebih praktis daripada lodruk"

Supaya lebih berwarna, konser musik tersebut diselingi dengan penampilan peragaan busana (fashion show) hasil kolaborasi antara istri Pak Darsono dan perancang busana terbaik di Pamekasan. Para modelnya direkrut dari para siswi sekolah menengah atas di sana, seperti siswi SMEA, SMAN 1 Pamekasan (SMAN pertama dan tertua di pulau Madura), dan SKKA (kemudian menjadi SMKK dan sekarang SMK 3). Proses seleksi dan perekrutan para model peragaan busana ini tidak terlalu sulit. Karena semua sekolah itu hanya berada di Pamekasan dan satu-satunya di Madura. Istri Pak Darsono yang berprofesi sebagai guru dan memiliki jabatan penting di dinas pendidikan sangat mudah melakukan apa saja untuk mempersiapkan kegiatan peragaan busana. Mereka yang terpilih sebagai para modelnya merasa sangat senang gembira. Selain bisa bersama dan bertemu langsung dengan musisi hebat dari Madura dan band ternama ibu kota, mereka juga akan dikenal oleh siapa saja yang menontonnya. Tetapi, peragaan busana ini berlangsung amat singkat, tidak lebih dari satu jam saja. Di deretan kursi belakang penonton terdengar teriakan yang mengganggu jalannya peragaan busana. "Molaèh, molaèh, molaèh", teriakan penonton itu agar penampilan keseluruhan band segera dimulai (molaèh).

Agar tidak berujung ricuh, maka 4B keluar dari balik ruangan dan segera memainkan lagu pembuka. Diawali pukulan senar gitar meraung-raung berulang-ulang sebagai intro akan memainkan lagu garang. Sang vokalis berteriak keras (nyaréng): "do you want revolution?". Entah tahu atau tidak arti kalimat itu dengan padu para penonton menjawab: "want-want”. Semua personel 4B menahan tawa. Lagu pembuka berjudul Revolution karangan The Beatles lalu dimainkannya. Karya The Beatles berikutnya yang dipentaskan oleh mereka adalah Hey Jude, dan Let It Be, diselingi lagu dari The Mercy's (Tiada Lagi), Koes 
Plus (Tul Jaenak dan Bis Sekolah), Panbers (Bye-Bye), dan karya band anak bangsa terkenal lainnya. Majabena membawakan dua lagu andalannya, Si Boncel karya Titik Shandora, dan The Mother dari The Beatles. Dengan vokal merdunya Anik melantunkan Si Boncel secara mulus dengan diakhiri gemuruh tepungan penonton. Lagu The Mother yang membutuhkan suara tinggi dibawakan Yul Rusli. Ketika Yul menyanyikan lagu itu seisi ruangan hening seolah sedang mengingat ketabahan ibu mereka di rumah masing-masing. Pretty Sister turut merasakan adanya suasana kepedihan yang sangat mendalam. Air mata istri Pak Darsono juga menetes tak tertahankan. Selesai bernyanyi, nyaris tidak ada satupun yang bertepuk tangan untuknya karena masih terbawa suasana penghayatan yang luar biasa. Sambutan meriah sayup-sayup mulai terdengar setelah salah seorang anggota Pretty Sister berdiri sambil bertepuk tangan. Sejak saat itulah, kedua penyanyi cilik Majabena ini mendapatkan julukan baru di kalangan masyarakat pecinta musik pop/rock. Anik dijuluki "Si Boncel" dari Madura dan Yul disebut "The Mothernya" Madura. Hingga kini julukan tersebut masih melekat kuat pada diri mereka berdua. Keduanya sekarang punya profesi yang sama, sama-sama menjadi dosen di kampus berbeda: Anik di Unira (Universitas Madura), dan Yul di Unesa (Universitas Negeri Surabaya).

Konser musik yang berhasil melambungkan nama band 4B berdampak pada undangan mengisi pesta pernikahan yang terus memadat dari waktu ke waktu. Di musim pernikahan orang Madura, terutama di bulan-bulan 'baik' berdasarkan perhitungan kalender Islam seperti Maulud, Rejjeb, dan Syawal, 4B bisa mengisi acara hingga sebulan penuh, siang dan malam. Padatnya jadwal manggung membuat Suk sempat pingsan di atas panggung karena sangat kelelahan. Kejadian dramatis ini tidak menyurutkan langkahnya memenuhi jadwal bermusik. Di luar musim pernikahan, mereka bisa tampil paling banyak 5 kali dalam sebulan. Beberapa di antaranya mengisi acara ulang tahun anak pejabat, pertemuan instansi pemerintahan, hari-hari besar, dan program perbankan (terutama BRI yang merupakan bank pertama di Madura). Dengan banyaknya permintaan pesanan mengisi kegiatan hiburan dari berbagai kalangan itu maka mereka harus mengkolaborasikan pilihan lagu dan musik antara pop, rock, dan melayu keroncongan. Mereka menyadari tidak mungkin pada pesta pernikahan dari awal hingga akhir disuguhkan lagu rock. Mereka tahu diri dan sadar waktu kapan lagu halus (pop) dan energik (rock) itu dimainkan. Lagu-lagu rock tidak akan dimainkan selama sesi makan-makan karena bisa menyebabkan tenggorakan tamu tersendat atau mengganggu selera makan mereka. Lagu rock dimainkan pada sesi terakhir acara. Akhir acara resmi pernikahan atau pertemuan formal seakan menjadi tradisi dalam sekejap berubah menjadi konser musik rock. Orang-orang yang awalnya menonton malu-malu langsung berhamburan ke depan, mereka saling berebut posisi sedekat mungkin dengan panggung supaya sebisa mungkin berinteraksi dengan pemain 4B sekaligus merasakan getaran energi musikalitasnya.

Begitu tenarnya nama 4B di pulau Madura muncul norma baru tak tertulis di kalangan masyarakat bahwa tanpa suguhan hiburan mereka prosesi pesta pernikahan tampaknya terasa kurang meriah. 4B seakan menjadi idola baru di dunia permusikan dan hiburan orang-orang Madura. Tetapi, ketenaran mereka juga menyulut ketegangan dan perselisihan yang tajam di antara band-band sejenis di kota tetangga sebelah timurnya, Sumenep. Semarak band dengan segala atributnya memang bermula dari Pamekasan sebagai ibu kota karesidenan Madura dan perlahan-lahan merambah ke sebelah timur kotanya. Di sebelah barat kota Pamekasan yakni, Bangkalan, masih kental dengan nuansa musik tradisional. Sedangkan Sampang yang kala itu sering disebutsebut sebagai 'kota mati' cenderung terpengaruh dengan tontonan musik yang berkembang di kota Pamekasan. Oleh sebab itulah, sangat beralasan jika saingan terberat 4B berasal dari kota Sumenep. Persaingan antara 4B dan band asal Sumenep berujung riskan dan membuat suasana permusikan di kalangan anak-anak muda semakin mencekam yang bermula dari pesta pernikahan di kota Sumenep. Peristiwa ini terjadi sekitar setahun pasca konser rock 4B berjalan sukses. Kala itu, seorang pejabat kaya raya di kota Sumenep menggelar pesta pernikahan anaknya. Dia mengundang AKA untuk mengisi rangkaian hiburan pestanya.

Sebagai sahabat lama yang datang dari luar Madura, AKA mengajak 4B menyaksikan Ucok dan kawan-kawanya bermain musik di sana. Atraksi panggung AKA yang memukau, dan aksi liar mengerikan Ucok sang vokalis membuat penonton terkesima. Tiba-tiba di sela pementasan, Ucok mengajak anggota inti 4B naik ke atas panggung menggantikan AKA agar suasana pesta pun semakin bertambah meriah dengan melibatkan band terkenal asal Madura. Tanpa berpikir panjang mereka merespon ajakan AKA. Tetapi, pada saat lagu Honky Tonky karya The Rolling Stones dibawakan, dari bawah panggung sebagian penonton berkecamuk menolaknya. Satu persatu batu dan bungkus kue pernikahan beserta isinya dilemparkan ke arah 4B. Para penonton tidak sudi apabila 4B bermain di pesta pernikahan itu karena mereka merupakan tamu yang tidak diundang. 4B dianggap menyerobot dan tidak menghormati acara tuan rumah (arebbu' téngka). AKA yang mencoba menengahi protes keras penonton turut dilempari juga. Suasana semakin memanas setelah beberapa penonton berusaha melompat ke panggung dan mencoba memukuli para pemain 4B. Perkelahian antara penonton dan pemain 4B tidak dapat terhindarkan lagi. Peralatan band dan perlengkapan panggung diobrak-abrik oleh gerombolan massa yang telah tersulut emosi. Alat musik band seketika itu juga berubah menjadi alat pemukul massa. Suanana anarkis ini mulai sedikit terkendali setelah beberapa pihak kepolisian setempat mengamankan semua anggota band, baik AKA maupun $4 \mathrm{~B}$, termasuk pihak yang diduga menjadi dalang kerusuhan pesta. Usut punya usut, kabarnya kericuhan itu terjadi karena anggota band Safitri yang dianggap saingan 4B (sekalipun band itu dikenal jago kandang, jarang sekali diundang ke luar Sumenep) duduk di antara para penonton dan memprovokasi mereka dengan alasan bahwa anggota 4B bukanlah orang asli Sumenep. Sejak peristiwa berdarah ini anak-anak muda Pamekasan dan Sumenep menabuh genderang perang. Kabar dari mulut ke mulut terus menyebar hingga ke pelosok desa. Anak-anak muda dari desa yang lebih banyak bergelut dengan seni tradisional seakan merasa terpukul martabatnya karena 4B merupakan band kebanggaan kota Pamekasan. Setiap pelaksanaan tradisi Ghubeng (ritual pacuan sapi tahunan se-Madura memperebutkan piala presiden RI bergilir) yang selalu ditempatkan di stadion gelora Pamekasan, anak-anak muda bersama sejumlah anggota band 4B 
turut hadir di sana. Bukan menyaksikan aduan sapi, melainkan menyelidiki dan mencari anak-anak muda dari Sumenep. Mereka seakan memiliki mata elang yang tajam. Sehingga, anak-anak muda Sumenep yang terindikasi terlibat pada peristiwa berdarah itu atau sebatas berteman dengan anggota band daerah asalnya langsung dipukuli beramai-ramai. Masa-masa mencekam dunia permusikan anak muda di Madura ini berlangsung bertahun-tahun. Kedua belah pihak tidak mau kalah, mengalah, dan terusmenerus saling mengancam maupun hanya mengirim pesan kepada kubu lawan melalui mekanisme konfrontasi dan stigmatisasi.

Ketika 4B diundang mengisi pesta pernikahan di Sumenep, anak-anak muda beserta pemain band tandingan yang menjadi penantang 4B mendapatkan kesempatan membalaskan dendamnya. Tetapi, Pak Darsono terlalu kuat untuk dikalahkan. Keluarganya yang memiliki jabatan penting di bidang kemiliteran dan pemerintahan ikut turun tangan mengamankan 4B yang akan pentas di Sumenep. Bahkan, penyanyi undangan 4B menyertakan anggota kodim Sumenep yang memiliki keahlian olah vokal. Pak Darsono juga menambah beberapa armada kendaraan 4B untuk mengangkut pendukungnya yang sebagian besar berasal dari kelompok anak-anak muda yang bersimpati pada 4B dan ingin membela reputasi daerahnya. Rangkaian pesta pernikahan itu berjalan sesuai rencana, aman dan damai. Namun, sepulang dari lokasi acara, di sepanjang batas keluar kota Sumenep yang dikelilingi hutan-hutan, puluhan anak muda berambut gondrong, berjaket kulit hitam, dan sejumlah orang-orang tua berkumis tebal mencegat iringan rombongan kendaraan 4B. Mereka ingin mengadu keberanian (jhung angkoan), membuka ajang perkelahian dengan anak muda Pamekasan yang mengiringi rombongan 4B. Darah yang mendidih di tubuh kedua kubu hampir memakan korban seandainya saja aparat keamanan gabungan polisi dan tentara tidak cepat datang. Sekalipun pihak keamanan hampir selalu cepat turun tangan, tidak berarti pertikaian kedua kubu bisa berakhir damai. Pada suatu waktu, Suk dan temannya sedang berkumpul di sekitar gedung Irama untuk menikmati jajanan favorit anak-anak muda Pamekasan, es Sudi Mampir. Tiba-tiba dari arah terminal opelet yang letaknya di sisi pojok barat gedung bioskop itu, Suk melihat beberapa anak band dari Sumenep. Gaya rambut dan penampilan pakaian anak band rock memiliki ciri khas dan mudah dikenali, mulai rambut panjangnya, bercelana jins warna gelap, berjaket hitam, hingga berkaos pendek digulung bagian lengannya. Mereka mencoba menyelinap dan mendengarkan logat bahasa Maduranya. Orang Madura memang peka dengan logat bahasa daerah barat dan timur pulaunya. Karena logat Sumenepnya yang kental itu maka, tanpa pikir panjang mereka memukulinya hingga korbannya babak belur (mes-mes). Keesokan harinya Suk ditampar oleh bapaknya dan dimaki-maki saudaranya karena ternyata di antara korban yang dipukulinya masih bagian dari keluarga dekatnya. Suk memang mengakuinya bahwa pada saat peristiwa itu:

"Saya termakan amarah karena tidak menyangka bahwa orang yang dipukuli di dekat terminal opelet itu masih kerabat dekat Saya. Mungkin orang tuanya datang ke rumah dan mengadu kepada kedua orang tua ketika Saya sedang tidak ada di rumah. Esok harinya Saya pun langsung dihukum dengan sangat keras oleh kedua orang tua dan kakak Saya tanpa banyak bertanya. Kejadian ini masih membekas hingga sekarang karena prinsip orang Madura keluarga itu adalah yang utama"

Mengamati perkembangan konflik antar anak band tersebut yang semakin memasuki situasi darurat, maka Pak Darsono bekerjasama dengan berbagai pihak keamanan dan instansi pemerintahan di Madura mencoba mengadakan konser perdamaian di halaman utama gedung karesidenan Pamekasan. Konser perdamaian ini diikuti oleh berbagai band dari seluruh pulau Madura berdasarkan undangan terbuka. Setidaknya, ada 15 band yang berinisiatif mengikuti konser ini. Sepuluh band di antara berasal dari Pamekasan, Sumenep sebanyak tiga band, satu band dari Sampang, dan satu band asal Bangkalan. Masing-masing dari para peserta membawakan 3 lagu bebas sesuai minat mereka. Hampir semua pesertanya yang ikut meramaikan konser tidak pernah ketinggalan membawakan lagu-lagu milik The Beatles dan The Rolling Stones. Tetapi, konser perdamaian ini di luar perkiraan karena menjadi ajang saling sabotase perangkat peralatan musikal agar mencederai reputasi pihak lawannya. Salah satu contohnya, pada saat 4B tampil tiba-tiba perangkat kotak bebunyiannya meledak dan lebih mengagetkan lagi setelah kotak itu dibuka berisi tumpukan sampah. Sebaliknya, ketika band dari Sumenep naik panggung, anak-anak muda Pamekasan cepat-cepat beranjak dari tempat duduknya, keluar menjauh dari lokasi acara, sebagian memalingkan mukanya dari penampilan mereka. Konser rock ini pada kenyataannya tidak menghasilkan proyek perdamaian apapun selain mempertegas kompetisi tidak sportif karena di antara pesertanya sebisa mungkin berhasil saling merendahkan, menjatuhkan, dan mencela kekurangan permainan musikalitas masing-masing. Suasana konser yang mirip pertunjukan gladiator ini mendorong peserta lain mengurungkan niatnya menampilkan hasil kreasi musikalitasnya. Dari 15 band peserta yang tercatat panitia menyusut drastis pada pelaksanaan konsernya menjadi 7 band saja, termasuk minus band dari Sampang dan Bangkalan.

Sekitar pertengahan tahun 1973, Pak Darsono mengalami kebangkrutan total. Saat itu, 4B mengisi pesta pernikahan yang diadakan oleh salah satu rekan kerjanya. Anggota 4B tidak pernah menyangka bahwa pesta pernikahan tersebut merupakan pesta terakhir bagi perjalanan musikal mereka. Setelah 4B menyelesaikan tugasnya mengisi acara pesta pernikahan, semua perlengkapan musiknya langsung digotong ke dalam mobil pengangkut lalu melaju menjauh dari iringan mobil khusus anggota band. Setelah semua anggota band 4B diantarkan ke rumah masing-masing, mobil pengantarnya juga tidak kembali lagi ke rumah Pak Darsono. Semua barang berharga peralatan band 4B dijual kepada kepala bank BRI setempat untuk menutupi kerugian proyek dan utang-utangnya. Barang berharga lainnya yang menjadi usaha dan bisnis Pak Darsono kabarnya sebagian dijual dengan harga murah dan sisanya lagi disita pihak bank. Popularitas 4B mulai meredup. Situasi ketegangan di antara anak band di Madura juga berangsur-angsur mereda sejak lawan terberat mereka, band 4B, tidak lagi 'mengudara' dari panggung ke panggung di seantero pulau Madura. Sebagian besar lawan-lawan 4B merasa kehilangan karena berkat munculnya 4B banyak band-band rock sejenis mengekor, meniru, bahkan, berharap mampu melampaui kesuksesannya. Bagi Suk pribadi, anggota inti 4B yang punya andil besar membentuk dan membesarkan band rock ini bahwa sumbernya bukan perkara utang memperlancar urusan proyek Pak Darsono sehingga band itu harus bubar ketika masa keemasannya sedang berkibar. Baginya yang sangat membekas dalam dirinya adalah ketabahan seorang istri dengan segala jerih payahnya berjuang mempertahankan mahligai 
Website : http://sosial.unmermadiun.ac.id/index.php/sosial

rumah tangganya sekalipun Pak Darsono dirasakannya terlalu sibuk dengan kesenangannya sendiri. Paling tidak, ada dua lagu rock yang boleh jadi memberi gambaran singkat merebaknya benih-benih kehancuran 4B, yakni, The Mother (The Beatles) dan Honky Tonky (The Rolling Stones). Lagu pertama, mengisahkan kegigihan seorang ibu dalam membesarkan anak-anaknya. Sedangkan, lagu kedua mengisahkan perempuan lain yang daya bujuk rayunya mampu melelehkan hati lelaki perkasa dan melupakannya dari keutuhan keluarganya.

\section{IV.KESIMPULAN}

Musik populer di Madura secara rute kultural bermula dari tengah pulaunya, kota Pamekasan yang secara historis sering dikenal sebagai ibu kotanya pulau Madura di masa silam. Sebagai ibu kota Madura, kota Pamekasan menjadi pusat hiburan, pendidikan, dan perdagangan, termasuk pula pusat kemunculan musik populer di Madura. Kemunculannya tidak semudah telur induk ayam menetaskan anaknya. Sebagai daerah yang kala itu masih didominasi seni musik tradisionalnya, tentu saja kerikil tajam harus dihadapi oleh kelompok band musik populer pada awal mula kehadirannya di tengah-tengah masyarakat Madura. Anak-anak muda sebagai pembawa awal musik populer di Madura tidak bisa tidak harus berhadapan dengan tuntutan masyarakat, generasi tuanya, ataupun 'orang tua' mereka yang sangat mencintai seni musik tradisionalnya. Tetapi, penanda kemoderenan yang merupakan konsekuensi perjumpaan bangsa Indonesia dengan globalisasi telah membuka pintu peluang sekaligus kesempatan bagi anak-anak muda Madura yang rupanya sangat ingin mengubah dunia musikal orang Madura menjadi lebih berwarna dengan membuka tangan bagi berlangsungnya ekologi musik populer di Madura sehingga fenomena sosial budaya musikal ini tampaknya terasa sulit sekali terbendung oleh generasi tuanya, bahkan, masyarakat Madura secara lebih luas sekalipun. Pada akhirnya, 'orang tua' mereka dan sebagian besar orang Madura merelakan dirinya mengikuti keinginan dan kehendak anak-anak mudanya mendukungnya dengan cara memfasilitasi bakat musikal mereka melalui pembelian perangkatperangkat teknologi musik populer secara lengkap dan berkelas dunia. Ekologi musikal yang ditopang oleh kekuatan teknologi musikal ini pada perjalanannya menciptakan ekologi suara atau bebunyian musik populer hingga menyebar dan bergema hingga ke pelosok Madura, bahkan, terdengar hingga ke luar pulaunya. Penguasaan peralatan teknologi musikal tersebut turut berdampak pada pembukan rute pendidikan musik secara otodidak melalui budaya pembelajaran dengan orang-orang yang dianggap lebih menguasai teknik penggunaannya, terutama dari kota besar di luar pulau terdekatnya, Surabaya. Ekologi musik populer ini pada perkembangannya menciptakan rute sosial baru dalam konteks pertemanan dan kesetaraan musikal dengan kelompok musisi ternama dari luar pulau Madura. Hubungan pertemanan yang semakin tambah erat dan kapasitas menguasai teknologi musikal yang bertambah meningkat mengantarkan para musisi ini menemukan jalan ketersohoran atau keartisannya sendiri. Melalui musik populer anak muda inilah setidaknya berhasil mengubah kesan-kesan ketertinggalan dunia musikal orang Madura dengan dunia musikal orang translokal atau juga transnasionalnya. Sehingga, Madura tidak lagi dipandang sebelah mata dalam suatu perkembangan dan kemajuan dunia musikalnya, terutama dalam aspek musik populernya. Tetapi, ketertinggalan atau keterhambatan musik populer di Madura justru bukan karena tidak mampu untuk menyetarakan dirinya dengan dunia luarnya, melainkan, karena kondisi ketegangan dan persoalan internal orang Madura yang masih memberikan porsi tidak terbatas, bahkan, nyaris absolut terhadap keterlibatan peran generasi tua terhadap masa depan generasi mudanya, termasuk, masa depan musik populernya. Itulah sebabnya rute kultural musik populer di Madura tidak pernah terhampar mulus dan lurus, melainkan, terputus-putus, penuh lobang dan berkelok-kelok sehingga kesannya terlalu banyak tempat pemberhentian sebelum musik populer anak muda Madura memasuki ke rute bebas hambatan.

\section{UCAPAN TERIMA KASIH}

Penelitian panjang yang kemudian diambil bagian kecilnya untuk menjadi artikel jurnal ini tidak mungkin tanpa tim promotor dan segenap pengajar program studi kajian budaya dan media pada sekolah pasca sarjana lintas disiplin UGM. Termasuk juga, segenap mahasiswa, kolega dan pimpinan di prodi Sosiologi Unesa yang secara moril memberikan waktu luang untuk menyelesaikan riset dan tulisan ini. Tidak terkecuali, para kepala daerah se-Madura, tokoh masyarakat, aparat keamanan, dan segenap sahabat seperjuangan di kedai kopi 11/12 Pamekasan dan mereka yang hingga hari ini masih bergelut dengan dunia musik populer di Madura, Surabaya, Malang, dan sekitarnya. Lebih penting lagi adalah keluarga dan sahabat karib yang turut membantu biaya untuk merampungkan penelitian mandiri dan melelahkan ini.

\section{VI.DAFTAR PUSTAKA}

Abdullah, Said, 2011. Menuju Madura Modern Tanpa Kehilangan Identitas, Jakarta: Penerbit Taman Pustaka

Abdurachman, 1971. Sedjarah Madura, Sumenep: The Sun

Appadurai, Arjun, 1996. Modernity at Large, London: University of Minnesota Press

Appadurai, Arjun, 2006. Disjuncture and Difference in the Global Cultural Economy, (hal. 584-603), dalam Douglas dan Durham, G. Meenakshi (ed.), Media and Cultural Studies, Oxford: Blackwell Publishing

Attali, Jacques, 1985. Noise: The Political Economy of Music, London: University of Minnesota Press

Berber, Alonka-Kersovan, 1989. "Tradition and Acculturation as Polarities of Slovenian Popular Music (1981)", (hal. 73-89), dalam Frith, Simon (ed.), World Music, Politics and Social Change, Manchester and New York: Manchester University Press

Clifford, James, 1997. Routes: Travel and Translation in The Late Twentieth Century, London: Harvard University Press

De Jonge, Huub, 1989. Madura dalam Empat Zaman: Pedagang, Perkembangan Ekonomi, dan Islam, Jakarta: Gramedia

Denzin, K. Norman, 1995. The Cinematic Society, London, California, and New Delhi: SAGE 
Website : http://sosial.unmermadiun.ac.id/index.php/sosial

Djojoprajitno, Sahwanoedin, 1988. Madu Jaya I: Kenang-Kenangan Tentang Residen dan Para Pembantu Gubernur di Pamekasan, Pamekasan: Tidak Diterbitkan

Djojoprajitno, Sahwanoedin, 2005. Soenarto Hadiwidjojo Residen Madura Pelopor Pembangunan, Surabaya: Pustaka Amaliya

Frederick, H., William 1982. Rhoma Irama and The Dangdut Style: Aspects of Contemporary Indonesian Popular Culture, Indonesia, USA: Cornel University Press

Hadiwidjojo, Soenarto, 1959. Pamong Praja dan Sepuluh Tahun Pembangunan Desa, Pamekasan: Tidak Diterbitkan

Hammersley, M. \& Atkinson, P., 2007. Ethnography: Principles in practice (Third edition), New York: Routledge

Hammond, Andrew, 2005. Pop Culture Arab World, USA: ABC CLIO

Heryanto, Ariel (ed.), 2012. Budaya Populer Di Indonesia Pasca Orde Baru, Yogyakarta: Jalasutra

Holmes, Thom, 2016. Electronic and Experimental Music, New York \& London: Routledge

Ihde, Don, 1979. Technics and Praxis, Holland: D. Reidel Publishing Company

Ihde, Don, 1993. Postphenomenology: Essays in the Postmodern Context, Illinois: Northwestern University Press

Ihde, Don, 2007. Listening and Voice: Phenomenologies of Sound, USA: State University of New York Press

Kartodirjo, Sartono, 2014. Pengantar Sejarah Indonesia Baru: 1500 - 1900, Yogyakarta: Penerbit Ombak

Kotarba, A. Joseph dan Vannini, Phillip, 2009. Understanding Society Through Popular Music, New York \& London: Routledge

Kotarba, A. Joseph, 2013. Baby Boomer Rock 'n' Roll Fans, Lanham, Toronto, Plymouth \& UK: The Scarecrow Press

Kraidy, M. Narwan \& Murphy, D. Patrick (ed.), 2003. Global Media Studies, New York and London: Routledge

Kuntowijoyo, 1989. Agama Islam dan Politik: Gerakan-Gerakan Sarekat Islam Lokal di Madura, 1913 - 1920 (hal. 31-82), dalam De Jonge, Huub, (ed.), 1989. Agama, Kebudayaan, dan Ekonomi: Studi Interdisipliner Tentang Masyarakat Madura, Jakarta: Rajawali Press

Kusnadi, 2008. Strategi Pelestarian dan Pengembangan Bahasa dan Sastra Madura, Pamekasan: panitia kongres Bahasa Madura I

Laughey, Dan, 2006. Music and Youth Culture, Edinburgh: Edinburgh University Press

McDonald, Kevin, 1999. Struggle For Subjectivity: Identity, Action, and Youth Experience, UK: Cambridge University Press

Muakman, 2012. Bahasa Menunjukkan Bangsa, (hal. 29-35), Buletin Pakem Maddhu kapeng 33/Th.8/November, 2012

Nadjib, A., Emha, 2015. Orang Maiyah: Terang dalam Kegelapan, Kaya dalam Kemiskinan, Yogyakarta: Bentang

Notosudirdjo, S. Franki, R., 2011. Islam, Politics, and the Dynamic of Contemporary Music, (hal. 297-317) dalam Rasmussen, K., Anne, \& Harnish, D. David (Ed.), Divine Inspiration: Music and Islam in Indonesia, New York: Oxford University Press

Port, S. Ian, 2019. The Birth of Loud, New York, London, Toronto, Sydnes, \& New Delhi: Scribner

Rasmussen, K., Anne, \& Harnish, D. David (ed.), 2011. Divine Inspiration: Music and Islam in Indonesia, New York: Oxford University Press

Rifai, A. Mien, 1993. Lintasan Sejarah Madura, Surabaya: Yayasan Lebur Legga

Rifai, A. Mien, 2007. Manusia Madura, Yogyakarta: Pilar Media

Rifai, A. Mien, 2008. Pencendekiaan Bahasa Madura: Kiat Pengembangannya dalam Menghadapi Tantangan Era Informasi dan Globalisasi, Pamekasan panitia kongres Bahasa Madura I

Robertson, Rolland, \& White, E. Kathleen, 2007. What Is Globalization?, dalam Ritzer, G., (ed.), The Blackwell Companion to Globalization, USA: Blackwell Publishing

Sakrie, Denny, 2015. 100 Tahun Musik Indonesia, Jakarta: Gagas Media

Schafer, R. Murray, 1977. The Soundscape, USA: Destiny Books

Schimmel, Annemarie, 2005. The Role of Music in Islamic Mysticism (hal. 8-18), dalam Hammarlund, dkk. (ed.), Sufism, Music, dan Society, Istanbul Swedish Research Institute

Sen, Krishna, \& Hill, David, 2004. “Global Industry, National Politics: Popular Music in 'New Order' Indonesia”, (hal. 75-88), dalam Refashioning Pop Music in Asia, London and New York: Routledge Curzon

Sen, Krishna, \& Hill, David, 2007. Media, Culture, And Politics in Indonesia, Jakarta and Kuala Lumpur: Equinox Publishing

Shofan, Moh., 2014. Rhoma Irama: Politik Dahwah Dalam Nada, Depok: Imania

Simatupang, Lono, 2013. Pergelaran: Sebuah Mozaik Penelitian Seni-Budaya, Yogyakarta: Jalasutra

Sutjipto, 1977. Madura dan Jawa Timur (Beberapa Catatan Tentang antar Hubungan) (hal. 174-190), dalam Madura I, Jakarta: Departemen Pendidikan dan Kebudayaan R.I dalam rangka kerja sama Indonesia - Belanda

Theodore, KS., 2013. Rock 'n Roll: Industri Musik Indonesia, Jakarta: Kompas

Tour, A., Pramoedya, 2002. Arus Balik, Jakarta: Hasta Mitra

Wallach, Jeremy, 2008. Modern Noise, Fluid Genres: Popular Music In Indonesia, Madison: The University of Winconsin Press

Weintraub, N. Andrew, 2003. Dangdut Stories, New York: Oxford University Press

Wicke, Peter, 1897. Rock Music: Culture, Aesthetics, and Sociology, UK: Cambridge University Press

Willis, Paul, 2000. The Ethnography Imagination., UK: Polity

Willis, Paul, 2014. Profane Culture, United Kingdom: Princeton University Press

Wiyata, Latief, 2002. Carok: Konflik Kekerasan dan Harga Diri Orang Madura, Yogyakarta: LKiS

Yampolsky, Bradford, Philip, 2013. Music and Media in the Dutch East Indies: Gramophone Record and Radio in the Late Colonial Era, 1903-1942, USA: Disertasi di Univeristy of Washington

Zainalfattah, 1912. Sedjarah Tjaranja Pemerintahan di Daerah-Daerah di Kepulauan Madura Dengan Hubungannya, (edisi lama/awal), Surabaya: Paragon Press 